\title{
Cardioprotective Effects of Quercetin in Cardiomyocyte under Ischemia/Reperfusion Injury
}

\author{
Yi-Wen Chen, ${ }^{1}$ Hsiu-Chuan Chou, ${ }^{2}$ Szu-Ting Lin, ${ }^{1}$ You-Hsuan Chen, ${ }^{1}$ Yu-Jung Chang, ${ }^{3}$ \\ Linyi Chen, ${ }^{3}$ and Hong-Lin Chan ${ }^{1}$ \\ ${ }^{1}$ Institute of Bioinformatics and Structural Biology and Department of Medical Sciences, National Tsing Hua University, \\ 101 Kuang-Fu Road, Section 2, Hsinchu 30013, Taiwan \\ ${ }^{2}$ Department of Applied Science, National Hsinchu University of Education, Hsinchu 30013, Taiwan \\ ${ }^{3}$ Institute of Molecular Medicine and Department of Medical Science, National Tsing Hua University, Hsinchu 30013, Taiwan
}

Correspondence should be addressed to Hong-Lin Chan; hlchan@mx.nthu.edu.tw

Received 10 August 2012; Revised 22 November 2012; Accepted 7 February 2013

Academic Editor: Peng Nam Yeoh

Copyright (c) $2013 \mathrm{Yi}$-Wen Chen et al. This is an open access article distributed under the Creative Commons Attribution License, which permits unrestricted use, distribution, and reproduction in any medium, provided the original work is properly cited.

\begin{abstract}
Quercetin, a polyphenolic compound existing in many vegetables, fruits, has antiinflammatory, antiproliferation, and antioxidant effect on mammalian cells. Quercetin was evaluated for protecting cardiomyocytes from ischemia/reperfusion injury, but its protective mechanism remains unclear in the current study. The cardioprotective effects of quercetin are achieved by reducing the activity of Src kinase, signal transducer and activator of transcription 3 (STAT3), caspase 9, Bax, intracellular reactive oxygen species production, and inflammatory factor and inducible MnSOD expression. Fluorescence two-dimensional differential gel electrophoresis (2D-DIGE) and matrix-assisted laser desorption ionization time-of-flight mass spectrometry (MALDI-TOF MS) can reveal the differentially expressed proteins of $\mathrm{H} 9 \mathrm{C} 2$ cells treated with $\mathrm{H}_{2} \mathrm{O}_{2}$ or quercetin. Although 17 identified proteins were altered in $\mathrm{H}_{2} \mathrm{O}_{2}$-induced cells, these proteins such as alpha-soluble NSF attachment protein ( $\alpha$-SNAP), Ena/VASP-like protein (Evl), and isopentenyl-diphosphate delta-isomerase 1 (Idi-1) were reverted by pretreatment with quercetin, which correlates with kinase activation, DNA repair, lipid, and protein metabolism. Quercetin dephosphorylates Src kinase in $\mathrm{H}_{2} \mathrm{O}_{2}$-induced $\mathrm{H} 9 \mathrm{C} 2$ cells and likely blocks the $\mathrm{H}_{2} \mathrm{O}_{2}$-induced inflammatory response through STAT3 kinase modulation. This probably contributes to prevent ischemia/reperfusion injury in cardiomyocytes.
\end{abstract}

\section{Introduction}

Because of their high incidence and mortality rate, cardiovascular diseases have recently become a primary health concern worldwide. Myocardial ischemia/reperfusion injury, which causes excess reactive oxygen species (ROS) production that can lead to cardiac hypertrophy or dysfunction, is the most acute cardiovascular disease [1,2]. In 2010, Chou et al. showed that ROS may affect intercellular connections and cytoskeleton resulting in cell detachment, morphology change, or death. Src kinase also plays a key role in ROS-induced phosphorylation and cell damage in cardiomyocytes [2].

The ROS in this study includes hydrogen peroxide $\left(\mathrm{H}_{2} \mathrm{O}_{2}\right)$, singlet oxygen $\left(\mathrm{O}^{\circ}\right)$, superoxide $\left(\mathrm{O}^{2-}\right)$, and the hydroxyl radical $\left(\mathrm{OH}^{*}\right)$. Among these ROS species, $\mathrm{H}_{2} \mathrm{O}_{2}$ is the most stable and the most abundant in human cells. Although the optimal amount of ROS plays an important role in signal transduction, excess ROS causes cell damage [3]. $\mathrm{H}_{2} \mathrm{O}_{2}$ regulates signal transduction-related proteins by phosphorylating or modifying the active sites of proteins but also inhibits phosphatase activity [4].

Quercetin, a type of polyphenolic compound, has antiinflammatory, antiproliferation, anti-histamine, and antioxidant effects. Quercetin exists in many types of vegetables and fruits. Several reports have shown that quercetin has protective effects on different types of cells, including myocytes, testis, renal cells, and liver cells in ischemia/reperfusion injury [5]. A study conducted in 1992 showed that quercetin 


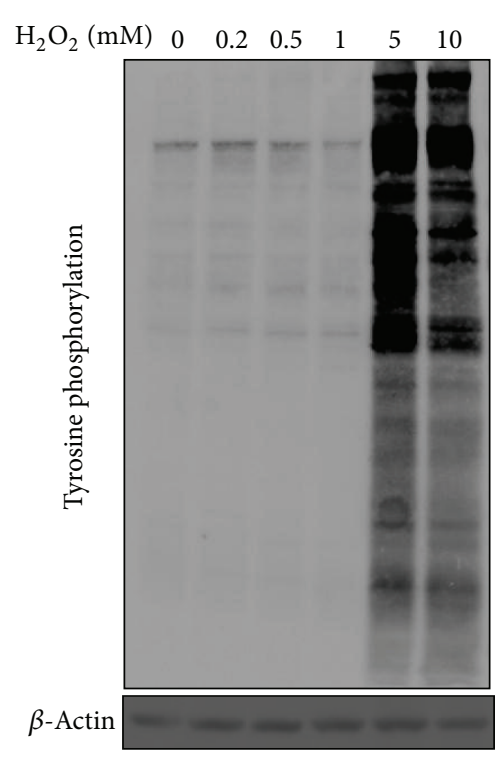

(a)

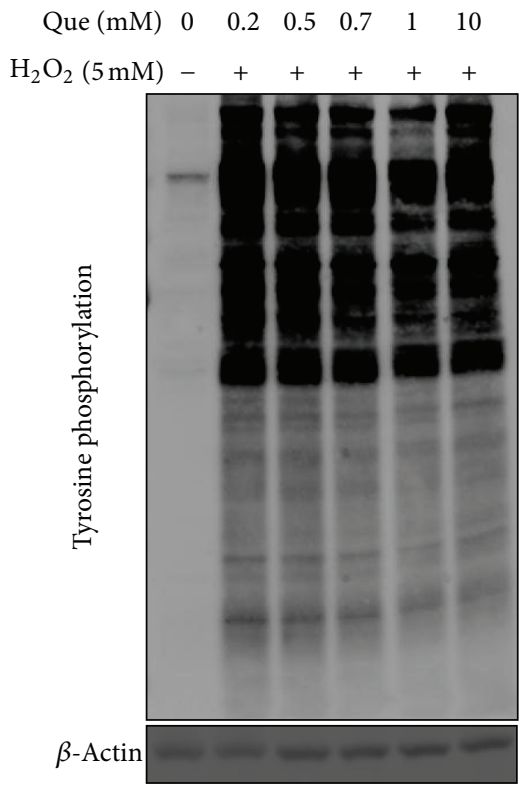

(b)

FIGURE 1: Hydrogen peroxide treatment induces tyrosine phosphorylation in H9C2 cells. (a) Total cell lysates were prepared from H9C2 cells treated with a range of $\mathrm{H}_{2} \mathrm{O}_{2}$ concentrations $(0,0.2,0.5,1,5$, and $10 \mathrm{mM})$ for $20 \mathrm{~min}$. H9C2 total cell lysate proteins were separated by $1 D$ SDSPAGE, transferred onto a PVDF membrane (Pall) electrophoretically, and then probed with specific primary antibodies antiphosphotyrosine and $\beta$-actin. (b) Effects of quercetin on $\mathrm{H}_{2} \mathrm{O}_{2}$-induced tyrosine phosphorylation in $\mathrm{H} 9 \mathrm{C} 2$ cells. The total cell lysates were prepared from $\mathrm{H} 9 \mathrm{C} 2$ cells pretreated with different quercetin concentrations $(0,0.2,0.5,0.7,1$, and $10 \mathrm{mM})$ for $1 \mathrm{~h}$ and then treated with $5 \mathrm{mM} \mathrm{H}_{2} \mathrm{O}_{2}$ for $20 \mathrm{~min}$. Cells were immunoblotted with phosphotyrosine and $\beta$-actin (upper image). $\beta$-Actin is a loading control for this experiment.

reduces the oxidative stress caused by ischemia/reperfusion in cardiomyocytes by inhibiting the xanthine dehydrogenase/xanthine oxidase system [6]. Several reports have also indicated that quercetin and isorhamnetin can scavenge ROS and inhibit the activation of ERK or MAP kinase in ROS-induced cardiomyopathy [7, 8]. In cancer therapy, combining quercetin with doxorubicin augmented the effects of doxorubicin in highly invasive breast cancer cells [9] and can protect cardiomyocytes from doxorubicin-induced toxicity by chelating iron, inducing antioxidant activity, and inhibiting carbonyl reductase [10]. Although quercetin has been reported to play a role in protecting myocardial cells from ischemia/reperfusion injury, its protective mechanism remains unclear in current knowledge.

Ischemia/reperfusion injury in cardiomyocytes is the result of myocardial inflammation [11]. Muthian and Bright showed that quercetin blocks the IL-12-induced inflammatory response through a signal transducer and activator of transcription 3 (STAT3) activation in T lymphocytes [12]. However, previous research failed to show a direct relationship between quercetin and STAT3-activated inflammation in cardiomyocytes. STAT3 is a transcription factor that plays an important role in numerous cytokine signaling transductions including cell survival, proliferation, cell cycle progression, and cell growth. STAT3 has two important phosphorylated and activate sites: Tyr705 and Ser727. STAT3 activation was phosphorylated at tyrosine 705 induced by various factors, including cardiotrophin-1, IL-6, tumor necrosis factor-alpha (TNF- $\alpha$ ), and interferon-gamma (IFN- $\gamma)[5,13]$. pY705-STAT3 is also essential for the dimerization of STAT3 and the translocation of STAT3 into the nucleus. In addition, STAT3 has been observed to be phosphorylated at serine 727 under oxidative stress to enhance the transcription activity of STAT3 in previous cerebral ischemia preconditioning study [14]. Moreover, The JAK2/STAT3 signaling pathways participate in an oxidative stress-induced immune response $[3,15]$.

Two-dimensional gel electrophoresis (2-DE) is a common tool for analyzing thousands of proteins in different biological samples and is complementary to LC-MS results. However, varying quantification between gels remains the primary challenge in 2 -DE. Therefore, $2 \mathrm{D}$-DIGE reduces the variation between gels and gels, which codetected the sample abundances on the same gel by using differential fluorescent labeling [2].

This study investigates the potential protective role of quercetin in $\mathrm{H}_{2} \mathrm{O}_{2}$-induced $\mathrm{H} 9 \mathrm{C} 2$ cell injury. We focus on the correlation between quercetin in cardiomyocytes and the cardioprotective role of Src kinase inhibition and inflammatory response of STAT3 using 2D-DIGE combined with MALDITOF MS and immunoblotting.

\section{Materials and Methods}

2.1. Chemicals and Reagents. Quercetin was purchased from Sigma-Aldrich (St. Louis, USA). The primary antibody 


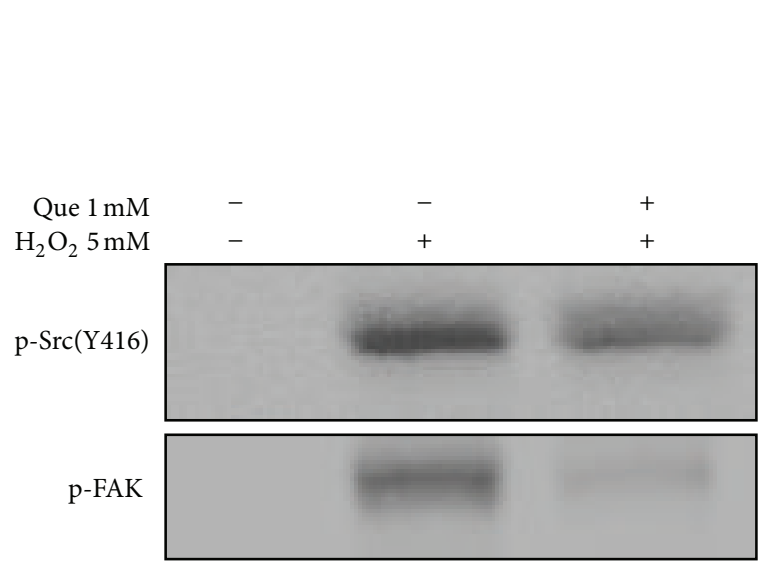

(a)

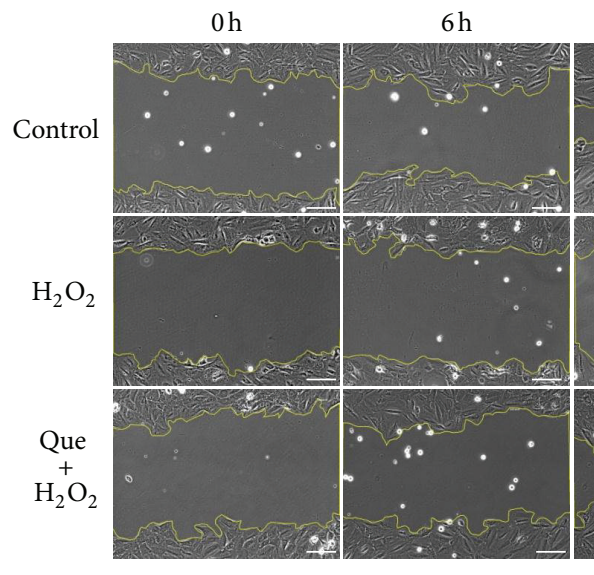

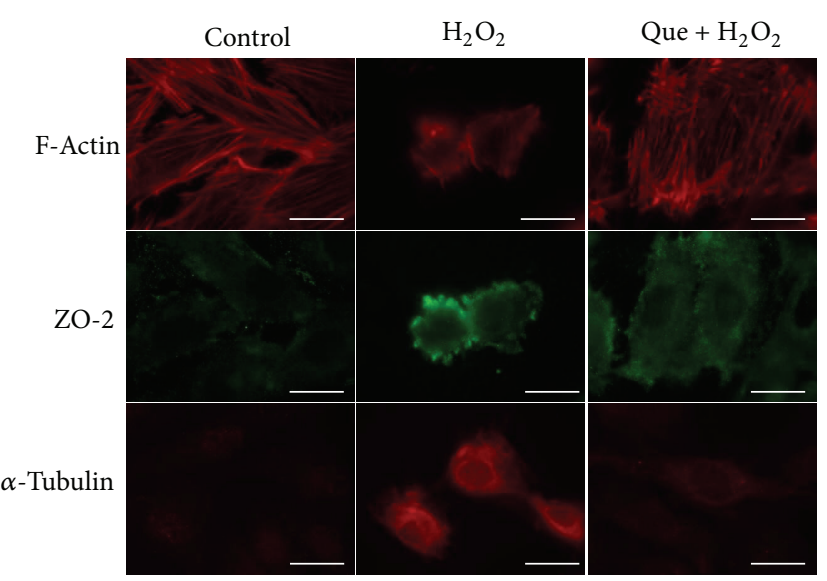

(b)
$24 \mathrm{~h}$

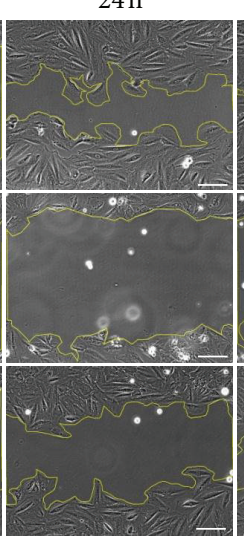

(c)

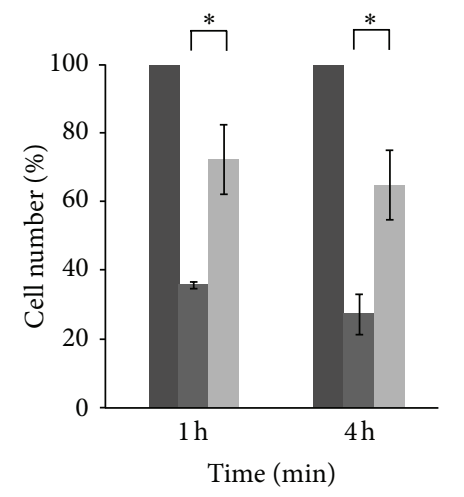

$$
\begin{aligned}
& \text { Control Que }+\mathrm{H}_{2} \mathrm{O}_{2} \\
& \mathrm{H}_{2} \mathrm{O}_{2}
\end{aligned}
$$

(d)

FIGURE 2: Effects of quercetin on the cell morphology, migration, and adhesion of $\mathrm{H}_{2} \mathrm{O}_{2}$-treated $\mathrm{H} 9 \mathrm{C} 2$ cells. (a) The expressions of phosphoSrc (Tyr-416) and phospho-FAK (Tyr-576/577) in H9C2 cells were detected using immunoblotting. (b) The cell morphology and protein location of proteins in $\mathrm{H} 9 \mathrm{C} 2$ cells were analyzed by immunostaining. Each set of fluorescence images was taken at the same exposure time. Scale bar $=20 \mu \mathrm{m}$. (c) The wound healing images were captured at different culture times $(0 \mathrm{~h}, 6 \mathrm{~h}, 24 \mathrm{~h}, 30 \mathrm{~h}$, and $42 \mathrm{~h})$ using a fluorescence microscope (Zeiss) after H9C2 cells were treated with $\mathrm{H}_{2} \mathrm{O}_{2}$ for 20 min or pretreated with quercetin for $1 \mathrm{~h}$. Scale bar $=100 \mu \mathrm{m}$. (d) Adhesion assays in which $\mathrm{H} 9 \mathrm{C} 2$ cells were treated with $\mathrm{H}_{2} \mathrm{O}_{2}$ for 20 min or pretreated with quercetin for $1 \mathrm{~h}$ and then incubated for $1 \mathrm{~h}$ and $4 \mathrm{~h}$ in a serum-free medium. After incubation, H9C2 cells were trypsinized, and the cell number was counted using a hemocytometer. Data represent the mean \pm standard deviation for 3 independent experiments and are represented as a percentage of the control. The control contains only serum-free DMEM. $\left({ }^{*} P<0.05\right)$. 


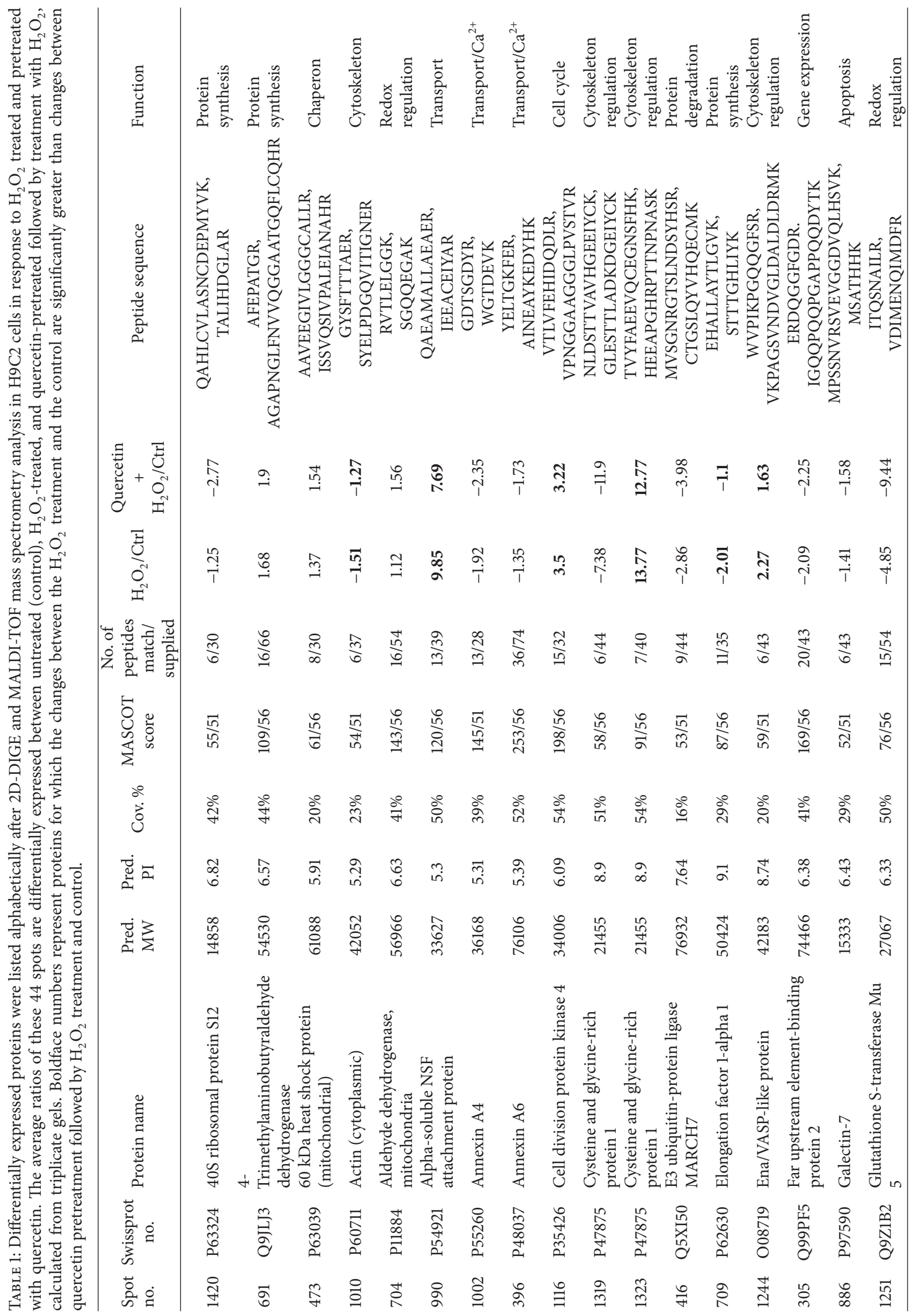




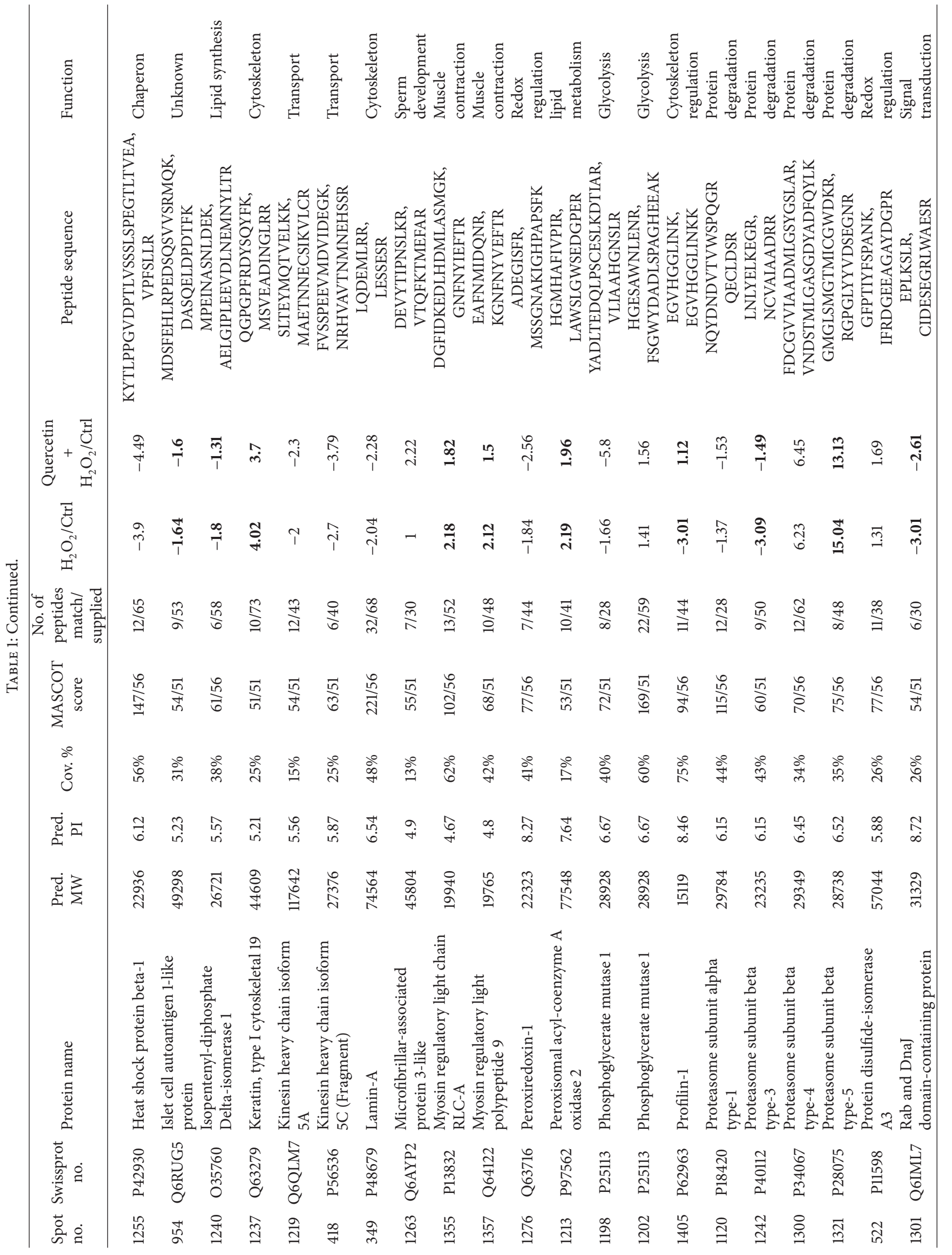




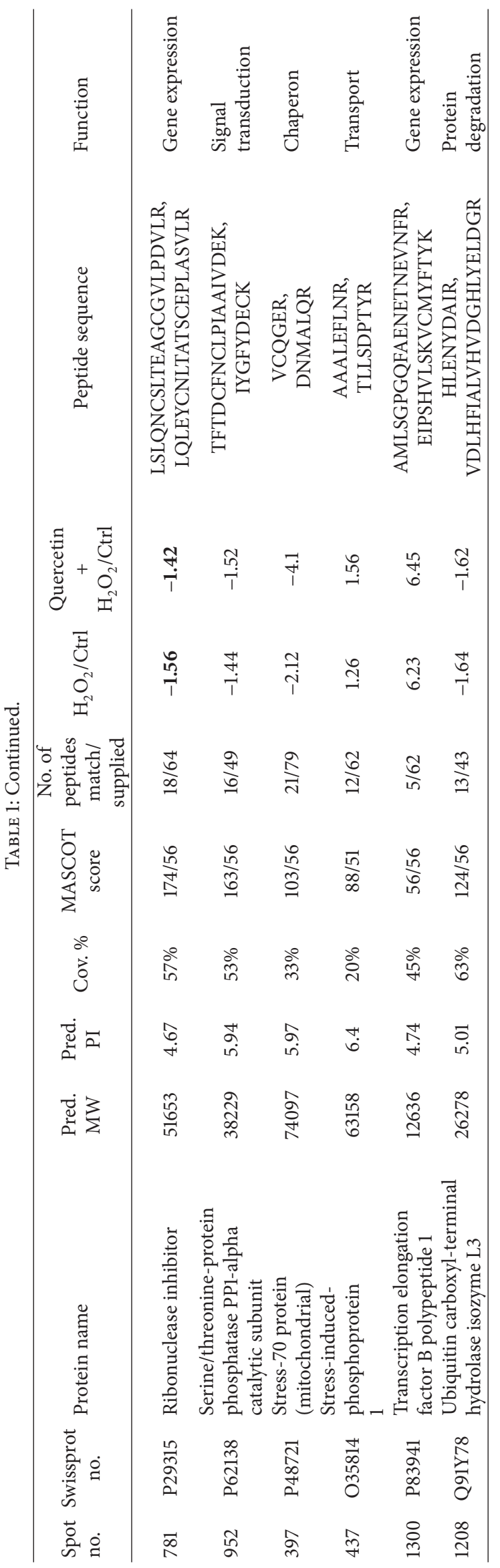




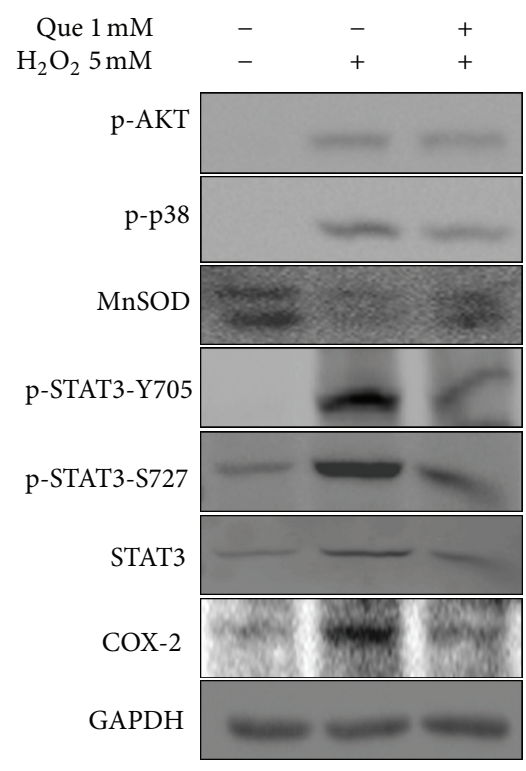

FIGURE 3: Effects of quercetin on the inflammatory response in $\mathrm{H}_{2} \mathrm{O}_{2}$-treated H9C2 cells. The expressed levels of phospho-Akt (Ser473), phospho-p38 (Tyr-180/182), Mn-SOD, phospho-STAT3 (Tyr705), phospho-STAT3 (Ser-727), COX-2, and STAT3 in H9C2 cell were detected by immunoblotting. GAPDH served as a loading control.

phopho-FAK, Bax, caspase9, Bcl-2, GAPDH, and STIP1 were purchased from Genetex (Hsinchu, Taiwan). Horseradish peroxidase and fluorescence conjugated secondary antibodies against mouse and rabbit were purchased from SigmaAldrich (St. Louis, USA). Annexin V-FITC and a propidium iodide (PI) labeling kit were purchased from Invitrogen. We purchased 2,7-dichlorofluorescein diacetate (DCFH-DA) from Molecular Probes. The chemicals and reagents of $2 \mathrm{D}$ DIGE were purchased from GE Healthcare (Uppsala, Sweden).

2.2. Cell Lines, Cell Culture, and Cell Treatment. The H9C2 rat cardiomyocyte cell line purchased from American Type Culture Collection (Manassas, VA, USA) was chosen as a cellular model for this study as this cell line retains the characteristics of isolated primary cardiomyocytes and has been used as a model in ischemia and reperfusion studies [2]. The H9C2 was cultured in Dulbecco's modified Eagle medium (DMEM) (Invitrogen) containing 10\% fetal bovine serum (FBS) at $37^{\circ} \mathrm{C}$. Cells cultured in normal growth medium were treated with various concentrations of $\mathrm{H}_{2} \mathrm{O}_{2}$ for $20 \mathrm{~min}$. H9C2 cells were pretreated with quercetin (Sigma) for $1 \mathrm{~h}$ followed by treatment with $\mathrm{H}_{2} \mathrm{O}_{2}$ for 20 min.

2.3. Immunoblotting. The methods of quantifying and separating cell lysates for immunoblotting were similar to our previous paper [2]. The primary antibodies used in this study included Src-phospho-Y416, phospho-FAK, phosphor-Y99, phospho-AKT, p38, Bax, caspase9, Bcl-2, GAPDH, CDK4, and STIP1.

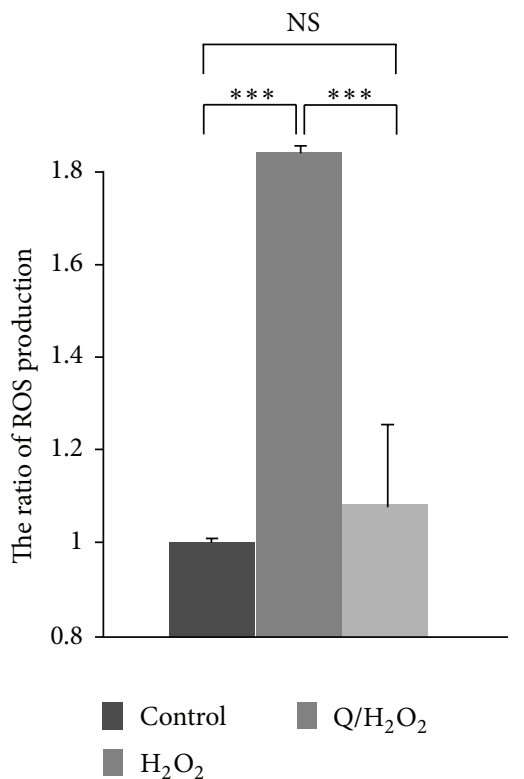

FIGURE 4: Effects of quercetin on ROS production in $\mathrm{H}_{2} \mathrm{O}_{2}$-treated H9C2 cells. The level of ROS in H9C2 cells was analyzed using a DCFH-DA assay. Values represent the mean \pm standard variation for 3 independent experiments performed in triplicate and are represented as a ratio of the control. The control contains only serum-free DMEM. $\left({ }^{* * *} P<0.001\right)$.

2.4. Immunostaining and Fluorescence Microscopy. For completing immunofluorescence staining, H9C2 cells grown on coverslips $(12 \mathrm{~mm})$ were treated with $5 \mathrm{mM} \mathrm{H}_{2} \mathrm{O}_{2}$ for $20 \mathrm{~min}$ alone, $1 \mathrm{mM}$ quercetin for $1 \mathrm{~h}$ prior to treatment with $5 \mathrm{mM}$ $\mathrm{H}_{2} \mathrm{O}_{2}$ for $20 \mathrm{~min}$, or left untreated [2]. The cell fixing, immunostaining, and fluorescence image analysis methods in this study were similar to our previous paper [2].

2.5. Wound Healing Assay. H9C2 cells ( $10^{5}$ cells/well) were incubated in 24 -well plate at $37^{\circ} \mathrm{C}$ for $12 \mathrm{~h}$ and then scraped with a $10 \mu \mathrm{L}$ tip and treated with $\mathrm{H}_{2} \mathrm{O}_{2}$ for $20 \mathrm{~min}$, pretreated with quercetin, or left untreated. H9C2 cells were incubated with medium containing $10 \%$ FBS, and a fluorescence microscope captured images at different incubation times $(0 \mathrm{~h}, 6 \mathrm{~h}$, $24 \mathrm{~h}, 30 \mathrm{~h}$, and $42 \mathrm{~h})$.

2.6. Adhesion Assays. H9C2 cells $\left(8 \times 10^{4}\right.$ cells/well $)$ were incubated in a $3 \mathrm{~cm}$ dish containing DMEM containing $10 \%$ FBS and treated with $1 \mathrm{mM}$ quercetin for $1 \mathrm{~h}$ followed by $5 \mathrm{mM} \mathrm{H} \mathrm{O}_{2} \mathrm{O}_{2}$ for $20 \mathrm{~min}$. After treatment, H9C2 cells were incubated with serum-free medium for $1 \mathrm{~h}$ and $4 \mathrm{~h}$ and then were counted. The cell culture environment and cell counting were similar to our previous study [2]. All conditions have been performed in duplicate-independent experiments.

2.7. Apoptosis Assay Using Flow Cytometry. H9C2 cells $\left(10^{6}\right.$ cells) were labeled with annexin V-FITC and PI at room temperature for $15 \mathrm{~min}$ and treated with $\mathrm{H}_{2} \mathrm{O}_{2}$, pretreated with quercetin, or left untreated. The FITC and PI fluorescence 


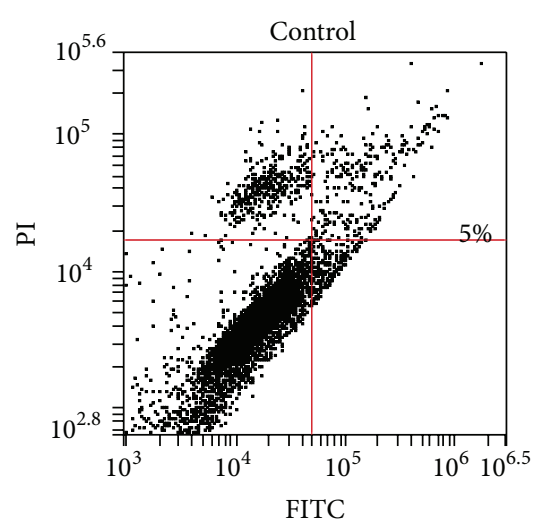

(a)

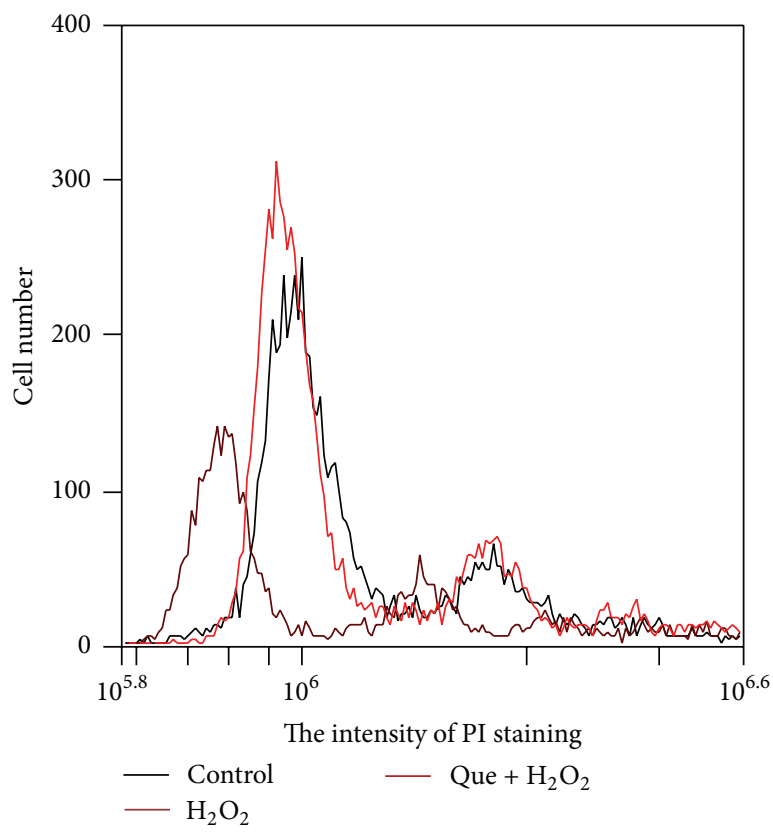

(d)

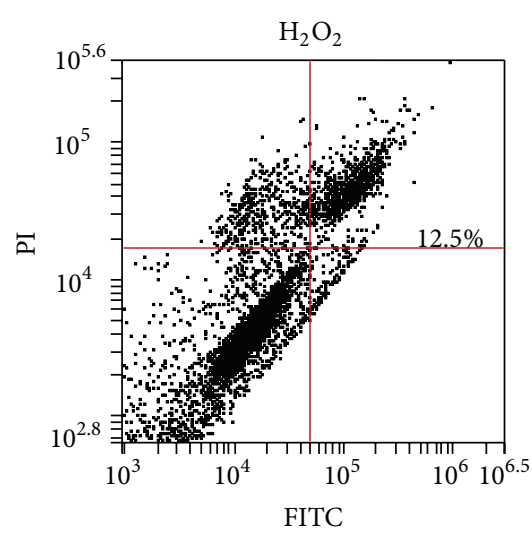

(b)

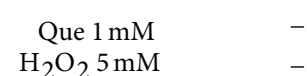

$\mathrm{H}_{2} \mathrm{O}_{2} 5 \mathrm{mM}$
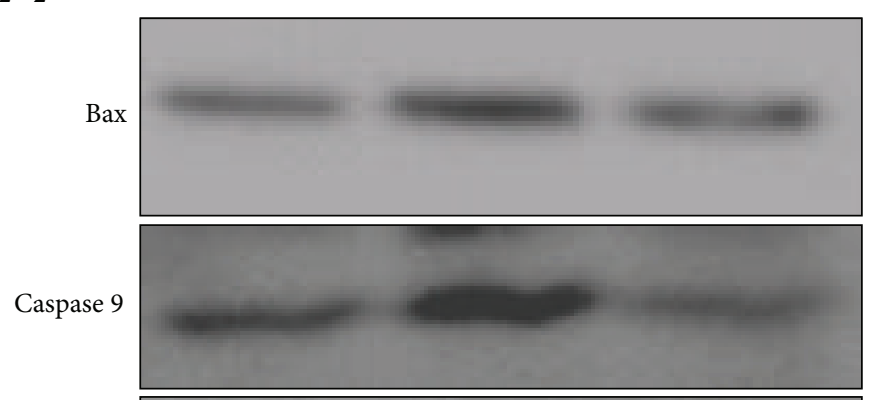

Bcl-2

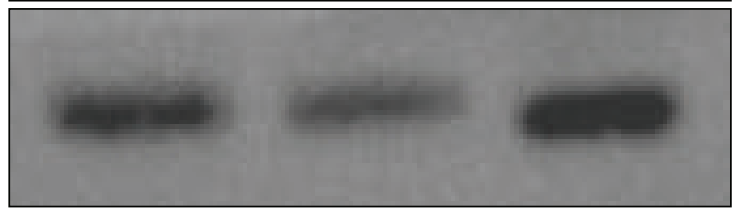

GAPDH

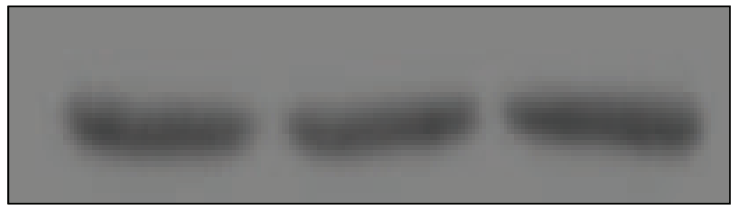

(e)

Figure 5: Effects of quercetin on cell apoptosis in $\mathrm{H}_{2} \mathrm{O}_{2}$-treated H9C2 cells. ((a), (b), and (c)) Typical dot plots of annexin V-FITC and PI are cells untreated, $\mathrm{H}_{2} \mathrm{O}_{2}$ treated, and quercetin pretreated followed by $\mathrm{H}_{2} \mathrm{O}_{2}$ treatment. The $x$-axis and $y$-axis represent the intensity of annexin V-FITC and PI, respectively. The lower left area of (a), (b), and (c) presented background staining by annexin V-FITC and PI in normal cells and apoptosis signals located in the right area. This figure is representative of 3 replicates. (d) The full lengths of DNA in H9C2 cells were detected by FACS. The $x$-axis shows the intensity of PI, and the $y$-axis shows the number of cells. (e) The levels of Bax, BCL-2, and caspase 9 in $\mathrm{H} 9 \mathrm{C} 2$ cells were detected by immunoblotting. GAPDH served as a sample loading control.

signals were recorded by fluorescence-activated cell sorting FACS (Accuri 6) and analyzed using CFlow plus software [2].

\subsection{Reactive Oxygen Species in Cells Were Detected Using} DCFH-DA Assay. H9C2 cells ( $10^{5}$ cells/well) were grown on a 24-well plate, treated with $\mathrm{H}_{2} \mathrm{O}_{2}$ for $20 \mathrm{~min}$, pretreated with quercetin for $1 \mathrm{~h}$, or left untreated. After washing, $\mathrm{H} 9 \mathrm{C} 2$ cells were incubated with $10 \mu \mathrm{M}$ of 2,7-dichlorofluorescin diacetate (DCFH-DA) at $37^{\circ} \mathrm{C}$ for $20 \mathrm{~min}$. Fluorescence was recorded by Spectra Max Gemini EM (Molecular Device) at an excitation wavelength of $488 \mathrm{~nm}$ and an emission wavelength of $504 \mathrm{~nm}[16,17]$.
2.9. 2D-DIGE and Gel Image Analysis in Gel Digestion and Protein Identification by MALDI-TOF MS. The experiments in this study used Cy-Dye labeling and comparative quantification methods to perform lysine-2D-DIGE analysis. Proteins were identified through MALDI-TOF MS with peptide mass fingerprinting (PMF) in our previous paper [2].

\section{Results}

3.1. Quercetin Pretreatment Suppresses Hydrogen PeroxideInduced Tyrosine Phosphorylation in Cardiomyocytes. $\mathrm{H}_{2} \mathrm{O}_{2}$, 


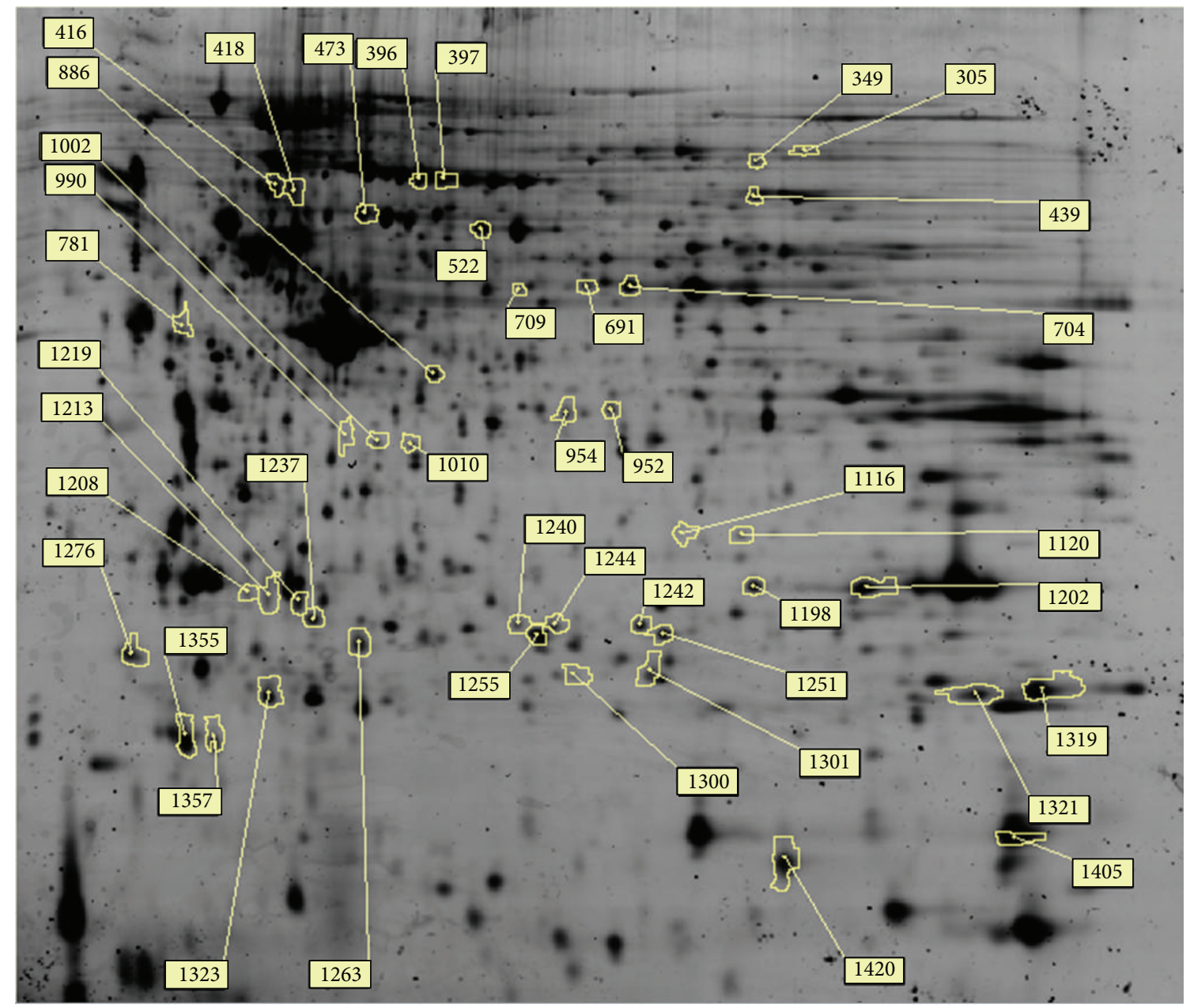

FIGURE 6: 2D-DIGE analysis of H9C2 cell proteome in response to $\mathrm{H}_{2} \mathrm{O}_{2}$ and quercetin treatment. $\mathrm{H} 9 \mathrm{C} 2$ cells were lysed and arranged for a triplicate electrophoresis using pH 3 to 10 nonlinear, $24 \mathrm{~cm}$ IPG strips, and SDS-PAGE after treatment. 2D-DIGE image of protein sample (Cy2) is shown here. The spot numbers represent differentially expressed proteins.

an important signal mediator, induces large scale of protein phosphorylation and protein modification resulting in cellular physiology alteration including cell morphology, adhesion, and viability. Because heart ischemia/reperfusion injury stimulates $\mathrm{H}_{2} \mathrm{O}_{2}$ production, $\mathrm{H} 9 \mathrm{C} 2$ cells were treated with varying $\mathrm{H}_{2} \mathrm{O}_{2}$ doses to find the optimal phosphotyrosine response. The optimal response represents the maximal ratio of phosphotyrosine intensity to $\mathrm{H}_{2} \mathrm{O}_{2}$ concentration by immunoblotting (Figure 1(a)). Results show that $5 \mathrm{mM} \mathrm{H}_{2} \mathrm{O}_{2}$ treatment led to a robust phosphotyrosine response, but the phosphotyrosine response decreased in $10 \mathrm{mM} \mathrm{H}_{2} \mathrm{O}_{2}$ cells. Quercetin may also play an important role in oxidative stressdamaged cells, and phosphotyrosine signals were detected with a range of quercetin followed by treatment with $5 \mathrm{mM}$ $\mathrm{H}_{2} \mathrm{O}_{2}$ (Figure 1(b)). These results reveal that $\mathrm{H} 9 \mathrm{C} 2$ pretreated with $1 \mathrm{mM}$ quercetin and subsequently treated with $5 \mathrm{mM}$ $\mathrm{H}_{2} \mathrm{O}_{2}$ induced a lesser phosphotyrosine response than that of $\mathrm{H} 9 \mathrm{C} 2$ cells treated with $5 \mathrm{mM} \mathrm{H}_{2} \mathrm{O}_{2}$. Subsequent experiments were carried out based on these $\mathrm{H}_{2} \mathrm{O}_{2}$ and quercetin treatment concentrations.
3.2. Quercetin Inhibits Hydrogen Peroxide-Induced Changes in Cell Morphology and Loss of Cell Adhesion. $\mathrm{H}_{2} \mathrm{O}_{2}$ stimulates the activation of Src kinase that regulates cytoskeleton, cell adhesion, and cell motility. Previous report indicated that $\mathrm{PP1}$, a Src kinase inhibitor, inhibits $\mathrm{H}_{2} \mathrm{O}_{2}$-induced Src kinase activation [2]. In this study, quercetin pretreatment reduces the tyrosine phosphorylation of Src kinase and FAK in $\mathrm{H}_{2} \mathrm{O}_{2}$ treated H9C2 cells (Figure 2(a)). The immunostained images represent the $\mathrm{H} 9 \mathrm{C} 2$ proteins against specific antibodies, including cytoskeleton protein (F-actin and $\alpha$-tubulin) and cell-cell interaction protein (ZO-2). Oxidative damage affects cytoskeleton proteins and ZO-2, effectively altering cell morphology (Figure 2(b)). Quercetin pretreatment improved changes in ROS-induced cell morphology.

In the wound healing assay, $\mathrm{H} 9 \mathrm{C} 2$ cell images were captured at different time points $(0 \mathrm{~h}, 6 \mathrm{~h}, 24 \mathrm{~h}, 30 \mathrm{~h}$, and $42 \mathrm{~h}$ ) using a microscope (Zeiss). Cells were untreated, $\mathrm{H}_{2} \mathrm{O}_{2}$ treated, and quercetin pretreated followed by hydrogen peroxide treatment (Figure 2(c)). After incubation, the closure areas of $\mathrm{H}_{2} \mathrm{O}_{2}$-treated $\mathrm{H} 9 \mathrm{C} 2$ cells were larger than those 

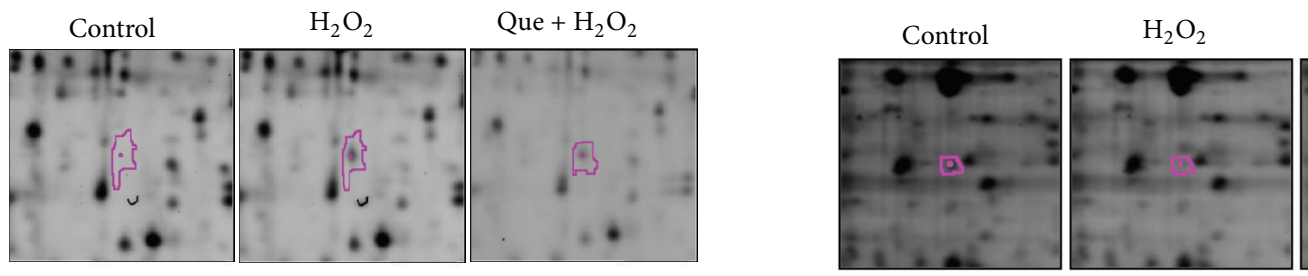

Que $+\mathrm{H}_{2} \mathrm{O}_{2}$
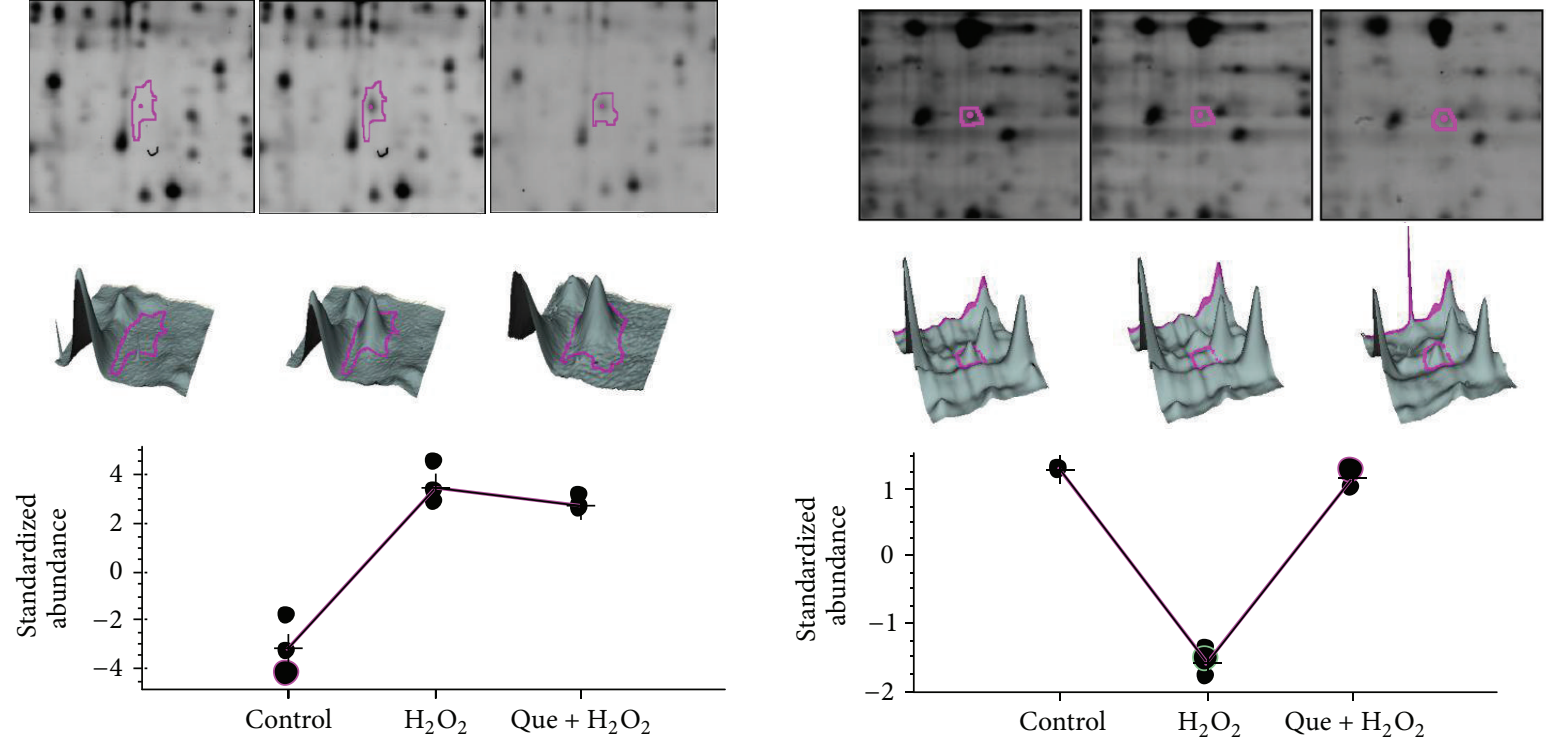

(a) No.990 alpha-soluble NSF attachment protein

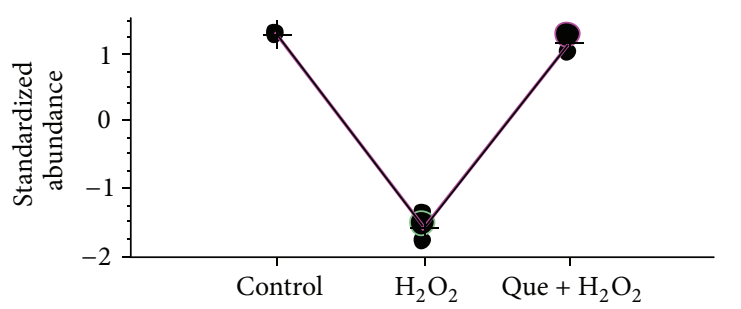

(b) No.709 elongation factor 1-alpha 1

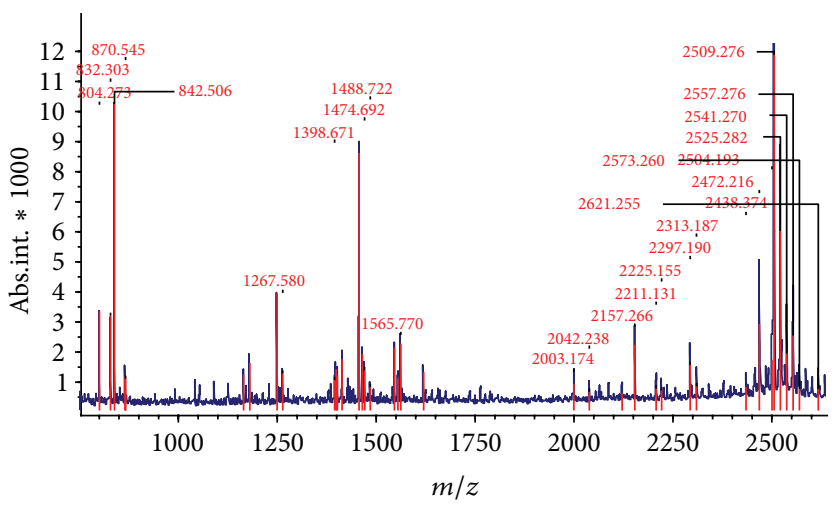

(c) No.990 alpha-soluble NSF attachment protein

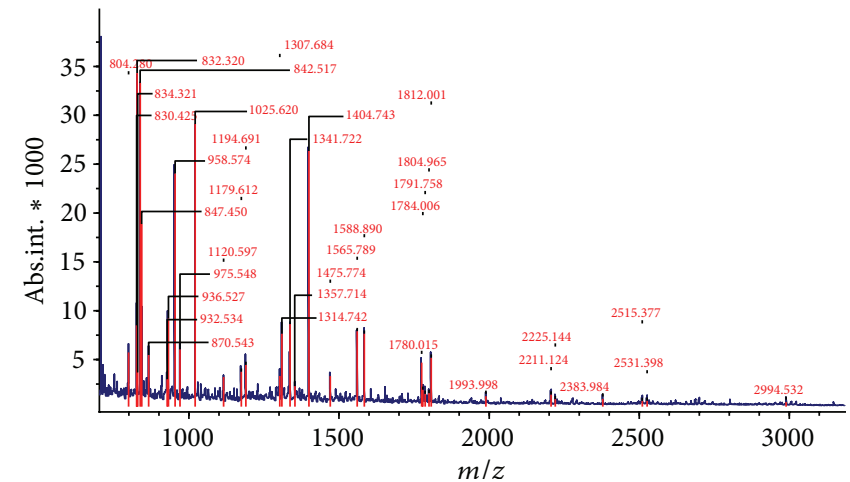

(d) No.709 elongation factor 1-alpha 1

FIGURE 7: Representative images of identified proteins spots and MALDI-TOF MS analysis of (a) alpha-soluble NSF attachment protein ( $\alpha$-SNAP); (b) elongation factor 1-alpha 1 display differentially expressed proteins among untreated, $\mathrm{H}_{2} \mathrm{O}_{2}$ treated, and quercetin-pretreated followed by $\mathrm{H}_{2} \mathrm{O}_{2}$ treatment. The differentially expressed levels of these proteins appear as 2D patterns (top images), 3D spot images (middle images), and protein abundance levels (bottom images). The PMF patterns were ((c) and (d)) from MALDI-TOF MS.

of untreated and quercetin pretreatment followed by $\mathrm{H}_{2} \mathrm{O}_{2}$ treatment.

An adhesion assay was also performed to analyze the effects of quercetin on ROS-damaged cardiomyocytes. H9C2 cells untreated, treated with $\mathrm{H}_{2} \mathrm{O}_{2}$ alone, or pretreated with quercetin were followed by treatment with $\mathrm{H}_{2} \mathrm{O}_{2}$. Cells were then incubated in a serum-free medium for $1 \mathrm{~h}$ or $4 \mathrm{~h}$. The adherent cells were counted after incubation. Results show that $\mathrm{H}_{2} \mathrm{O}_{2}$-treated cells had reduced adhesive ability; yet, this could be significantly improved by pretreatment with quercetin (Figure 2(d)). Thus, quercetin can stimulate cell migration and maintain cell adhesion in $\mathrm{H}_{2} \mathrm{O}_{2}$-damaged H9C2 cell. and p38 Kinase and the Expression of COX-2 in $\mathrm{H}_{2} \mathrm{O}_{2}$-Induced
H9C2 Cells. To determine whether quercetin affects cell signalings associated with inflammatory response and cell proliferation, we examined the activation of AKT, p38, and STAT3 and the expression of COX-2 and MnSOD in ROS-induced cardiomyocytes. Results show that excess ROS increased the phosphorylation of Akt, p38, and STAT3 (Tyr705 and Ser-727) and the level of COX-2 but repressed the expression of MnSOD in H9C2 cells. Quercetin significantly reduces the phosphorylation of STAT3 and level of COX2 and increases the expression of MnSOD in $\mathrm{H}_{2} \mathrm{O}_{2}$-treated cells (Figure 3). These results show that quercetin suppresses inflammation in $\mathrm{H}_{2} \mathrm{O}_{2}$-induced $\mathrm{H} 9 \mathrm{C} 2$ cells.

3.4. Pretreatment with Quercetin Suppresses ROS Production in $\mathrm{H}_{2} \mathrm{O}_{2}$-Treated $\mathrm{H} 9 \mathrm{C} 2$ Cells. DCF fluorescence revealed ROS production in $\mathrm{H} 9 \mathrm{C} 2$ cells induced by oxidative damage. 


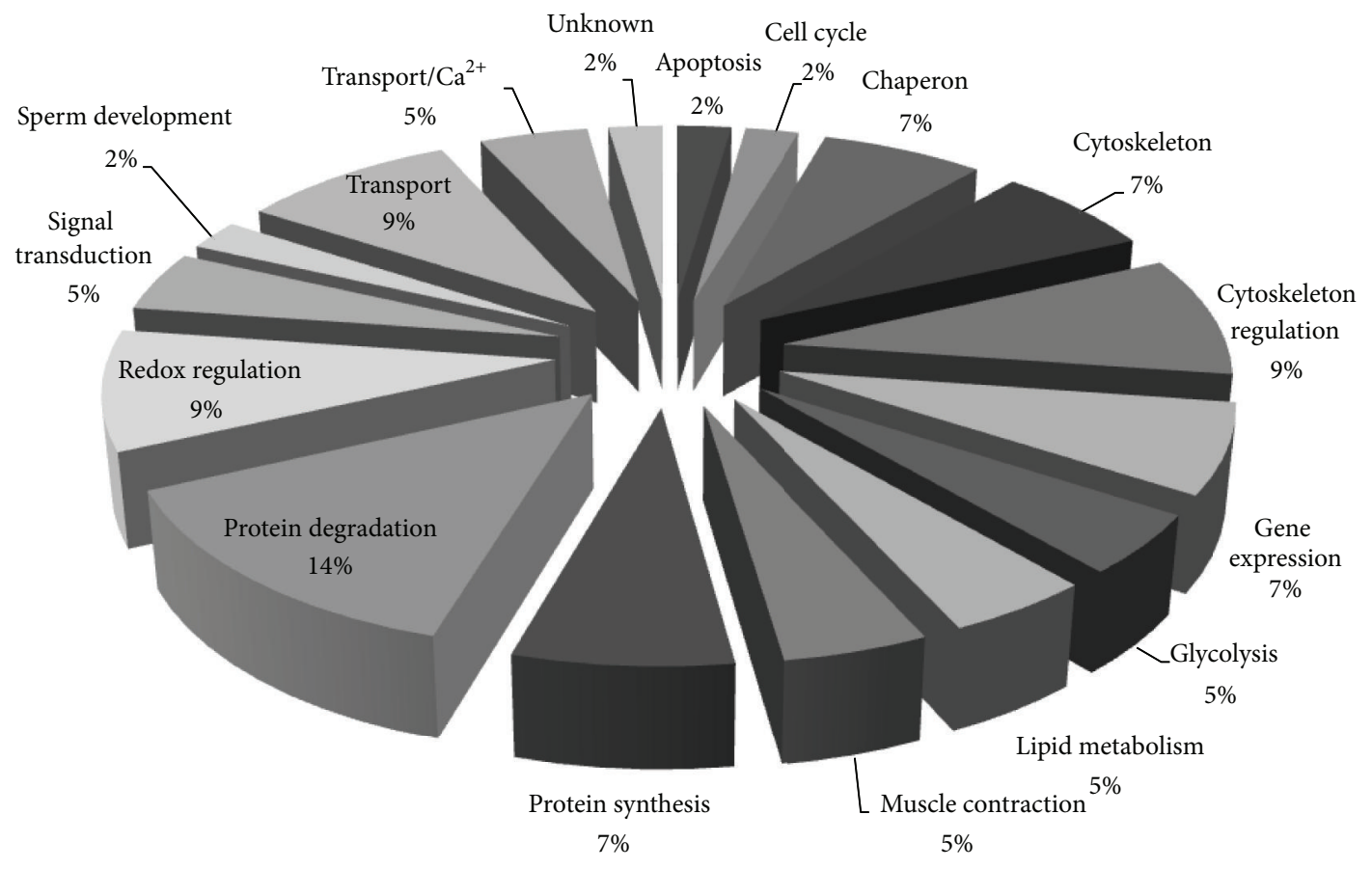

FIGURE 8: Percentage of functional distribution of differentially expressed proteins in $\mathrm{H} 9 \mathrm{C} 2$ cell responses to $\mathrm{H}_{2} \mathrm{O}_{2}$ and quercetin treatment based on proteomic analysis.
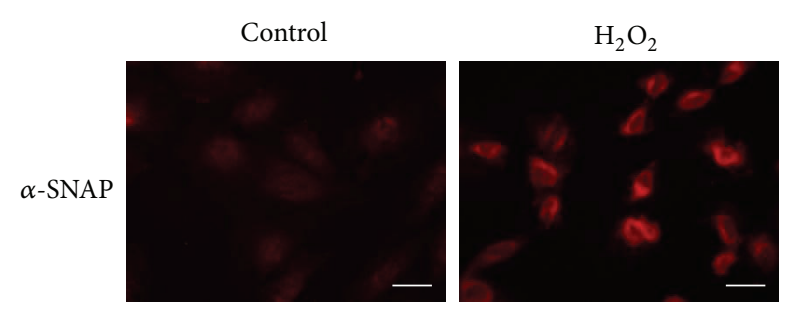

(a)
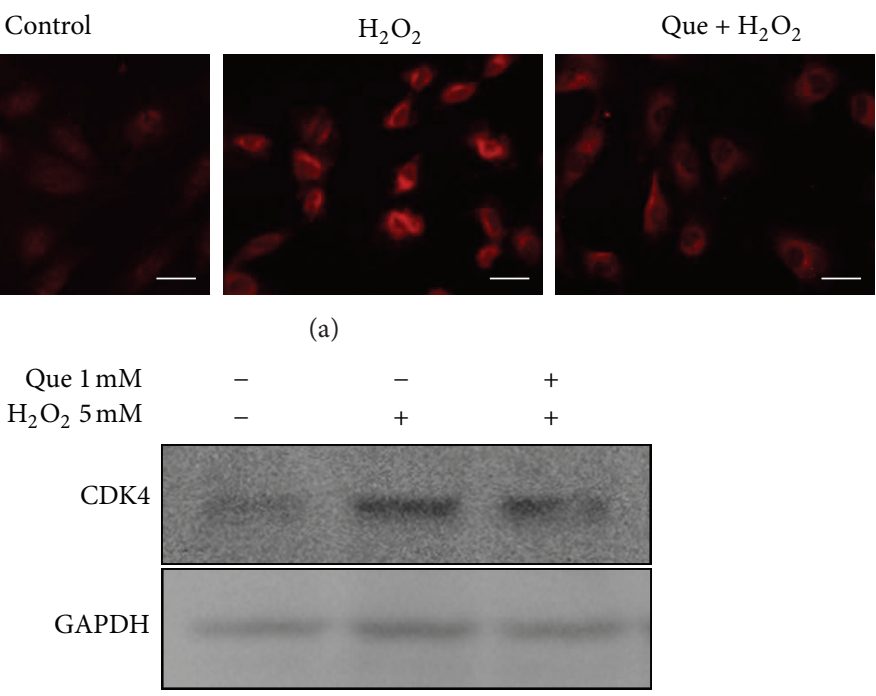

(b)

FIGURE 9: Comprehensive immunofluorescence images and immunoblotting analysis of the differentially expressed proteins identified by MALDI-TOF MS. (a) The differential expression and distribution of $\alpha$-SNAP in H9C2 cells responded to $\mathrm{H}_{2} \mathrm{O}_{2}$ and quercetin (Que) were analyzed using immunofluorescence. (b) Immunoblotting was performed to validate CDK4 and STIP1 in the H9C2 cell lysate. $\alpha$-Tubulin served as a loading control. Scale bar $=20 \mu \mathrm{m}$.

Excess ROS accumulated in $\mathrm{H}_{2} \mathrm{O}_{2}$-induced $\mathrm{H} 9 \mathrm{C} 2$ cells, but quercetin significantly inhibited $\mathrm{H}_{2} \mathrm{O}_{2}$-induced ROS production in cardiomyocytes (Figure 4).

\subsection{Quercetin Reduces Hydrogen Peroxide-Induced H9C2 Cell Apoptosis. Excess ROS production from ischemia/}

reperfusion-injured cardiomyocyte [18] alters redox homeostasis and induces cell apoptosis. During cell apoptosis, the asymmetric distribution of phospholipids of the plasma membrane gets lost and phosphatidylserine is translocated to the outer surface of the plasma membrane which has a high affinity to annexin V-FITC. PI can penetrate the cell 


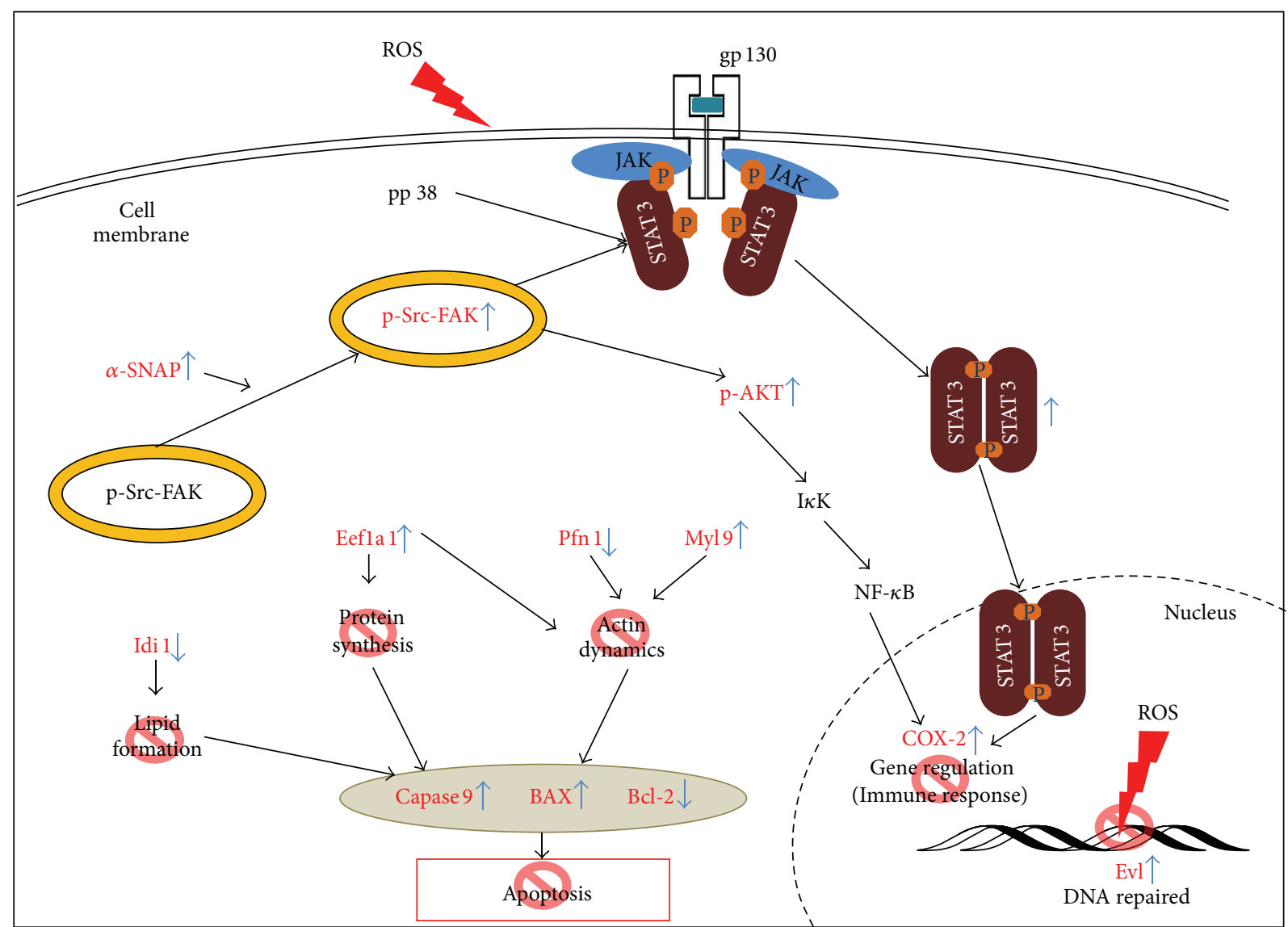

FIGURE 10: Model illustrating how quercetin protects cardiomyocytes from ROS treatment. ROS activates Src kinase and the overexpression of $\alpha$-SNAP. ROS-induced $\alpha$-SNAP causes phospho-Src-FAK complexes to move from the cytosol to a nearby inner cell membrane. ROSactivated p-Src and p-p38 stimulate the phosphorylation of STAT3 at tyrosine 705 and serine 727 . After p-Src kinase and p-p38 activated STAT3, the p-STAT3 dimerized to translocate into nucleus. The dimerization of p-STAT3 induces the proinflammatory response gene expression (i.e., COX-2) in oxidative stress. Ena/VASP-like protein (Evl), which participates in actin binding and homologous recombination, is upregulated in ROS-induced cells and can repair ROS-damaged DNA. Elongation factor 1-alpha 1 (Eefla1) decreased in oxidative stress resulting in cell death. Myosin regulatory light polypeptide 9 (Myl9), profilin-1 (Pfn1), and Eeflal are correlated with cytoskeleton, which may induce cell deadhesion and apoptosis. ROS inhibited the expression of isopentenyl-diphosphate delta-isomerase 1 (Idil) in cells that may block the formation of lipophilic molecular such as sterols, ubiquinones, and terpenoids. Quercetin may protect ROS-damaged cardiomyocytes via these routes (stop sign in red). The proteins (red) were altered in $\mathrm{H}_{2} \mathrm{O}_{2}$-dependant manner but reverted by pretreatment with quercetin.

nucleus when cells undergo apoptosis. Cell apoptosis was detected using FACS. The dot plots of annexin V and PI staining are analyzed using FACS, appearing in Figures 5(a), 5(b), and 5(c). The cell apoptosis rate increased from 5\% to $12.5 \%$ upon $\mathrm{H}_{2} \mathrm{O}_{2}$ treatment, whereas the cell apoptosis rate decreased to $5.5 \%$ after $\mathrm{H} 9 \mathrm{C} 2$ cells were pretreated with quercetin before $\mathrm{H}_{2} \mathrm{O}_{2}$ treatment. In addition, the PI staining signal of $\mathrm{H}_{2} \mathrm{O}_{2}$-treated $\mathrm{H} 9 \mathrm{C} 2$ shifted forward, compared to that of untreated cells and cells pretreated with quercetin followed by $\mathrm{H}_{2} \mathrm{O}_{2}$ (Figure 5(d)). The levels of Bax, Caspase 9, and $\mathrm{Bcl}-2$ were detected using immunoblotting for untreated H9C2 cells, treated $\mathrm{H}_{2} \mathrm{O}_{2}$, and pretreated quercetin followed by $\mathrm{H}_{2} \mathrm{O}_{2}$ treatment. ROS increased the expression level of apoptosis factors caspase 9 and Bax and reduced antiapoptosis marker Bcl-2 expression (Figure 5(e)). According to the data, quercetin can protect and stabilize the total chromosome of DNA in H9C2 cells from oxidative damage by inhibiting cell apoptosis and chromosome attrition.
3.6. 2D-DIGE Analysis of Untreated and $\mathrm{H}_{2} \mathrm{O}_{2}$-Treated $\mathrm{H} 9 \mathrm{C} 2$ Cells and Quercetin Pretreatment Followed by Treatment with $\mathrm{H}_{2} \mathrm{O}_{2}$. Three types of cell lysates were analyzed using 2D-DIGE. The results of 2D-DIGE analysis and DeCyder processing identified 1535 proteins spots, and 44 proteins showed differential expression $(\geqq 1.5$-fold or $\leqq-1.5$-fold; $P<0.05$ ) among these 3 conditions (Figure 6). Table 1 shows that 44 proteins were identified using MALDI-TOF MS and 17 protein spots of the 44 identified protein spots that displayed $\mathrm{H}_{2} \mathrm{O}_{2}$-dependent alteration could be reversed by pretreatment with quercetin (Table 1, boldface numbers). For example, the alpha-soluble NSF attachment protein ( $\alpha$-SNAP) (No.990) was upregulated (9.85-fold) in $\mathrm{H}_{2} \mathrm{O}_{2}$ treated cells, whereas quercetin reduced the overexpression of $\mathrm{H}_{2} \mathrm{O}_{2}$-treated $\alpha$-SNAP (7.69-fold). Protein spot number 1405 , which was identified as profilin-1, was downregulated in $\mathrm{H}_{2} \mathrm{O}_{2}$ treatment only ( -3.01 -fold) but showed no significant expression after quercetin pretreatment followed by 
$\mathrm{H}_{2} \mathrm{O}_{2}$ treatment (1.12-fold). These results suggest that the protective mechanisms of quercetin significantly reduced $\mathrm{H}_{2} \mathrm{O}_{2}$-induced damage in cardiomyocytes. Figure 7 shows the $2 \mathrm{D}$-gel images, $3 \mathrm{D}$ images, and protein abundances from untreated, $\mathrm{H}_{2} \mathrm{O}_{2}$ treated, and quercetin pretreated followed by $\mathrm{H}_{2} \mathrm{O}_{2}$ cells.

Figure 8 shows the functional distribution of identified proteins from 2D-DIGE results. Most of proteins identified using MALDI-TOF MS are related to the cytoskeleton (9\%), redox regulation (9\%), and protein degradation (14\%), implying that quercetin can reverse ROS damage to the cytoskeleton and redox homeostasis in cardiomyocytes.

3.7. Verification by Immunoblotting and Immunostaining. The levels of the alpha-soluble NSF attachment protein ( $\alpha$-SNAP) and cell division protein kinase 4 (CDK4) were examined by immunoblotting or immunostaining to validate the results of 2D-DIGE analysis. These results indicate that $\alpha$-SNAP and CDK4 were overexpressed in response to $\mathrm{H}_{2} \mathrm{O}_{2}$. However, quercetin suppressed ROS-induced $\alpha$-SNAP and CDK4 protein expression in H9C2 cells (Figures 9(a) and 9(b)). These data are consistent with 2D-DIGE results.

\section{Discussions}

Cardiovascular diseases have become a primary health concern worldwide in recent years. Ischemia/reperfusion injury in cardiomyocytes, which leads to excess ROS generation, is a particularly serious result of cardiovascular diseases. Many studies have focused on how to alleviate ischemia reperfusion-induced ROS in cardiomyocytes. For example, many plant molecules, including resveratrol, quercetin, sasanquasaponin, proanthocyanidin, safflower, and orientin, function as protectors in ischemia/reperfusion-damaged cardiomyocytes [19-23]. However, the role of quercetin in the ischemia/reperfusion injury of cardiomyocytes remains unclear.

According to previous reports, Src kinase regulates many cell signals, including cell adhesion, migration, proliferation, and apoptosis $[24,25]$. During oxidative stress, Src kinase induces cell death by inactivating PI-3 K, cell migration, and spreading [26]. PP1, a Src kinase inhibitor, can rescue ROS-damaged H9C2 cells by inhibiting cell apoptosis and enhancing cell adhesion/viability [2]. However, the inhibition of Src kinase activity with PP1 is generally unsuitable for mammalian cells. Alternatively, in our findings, H9C2 cells pretreated with quercetin for $1 \mathrm{~h}$ are protected against $\mathrm{H}_{2} \mathrm{O}_{2}$ induced apoptosis in this study. The role of quercetin in $\mathrm{H}_{2} \mathrm{O}_{2}$-treated cardiomyocytes is to inhibit inflammatory response and maintain cell physiology, including morphology, redox status, and metabolism, by regulating Src kinase, FAK, and STAT3.

The results of this study indicate that $\mathrm{H}_{2} \mathrm{O}_{2}$ stimulates the tyrosine phosphorylation of Src kinase and FAK, which affect cell morphology and tight junction proteins, leading to cell detachment [27]. Quercetin, however, inhibits the tyrosine phosphorylation of Src kinase and FAK which maintain cellcell interaction and morphology. Many studies have shown that quercetin protects retina, testis, neuron, cerebral, and cardiovascular cells from ischemia/reperfusion injury [2831]. This study further demonstrates that quercetin increases migration and survival in $\mathrm{H}_{2} \mathrm{O}_{2}$-treated cardiomyocytes (Figure 2).

$\alpha$-SNAP is a component of the soluble $\mathrm{N}$-ethylmaleimidesensitive fusion factor attachment protein receptors (SNAREs) complex required for vesicular transport between the endoplasmic reticulum and the Golgi apparatus. The major function of $\alpha$-SNAP is to recycle the SNARE complex. Several reports have shown that SNAREdependent trafficking is required for integrin signaling through a FAK/Src/PI3 K-dependent pathway [32], and the inhibition of SNARE-mediated exocytosis attenuates ischemia/reperfusion injury [33]. $\alpha$-SNAP may play a critical role in regulating Src kinase signaling and inducing ischemia/reperfusion injury in cardiomyocytes. This study shows that $\alpha$-SNAP was robust to overexpression (9.85-fold) in $5 \mathrm{mM} \mathrm{H}_{2} \mathrm{O}_{2}$-treated $\mathrm{H} 9 \mathrm{C} 2$ cells. However, pretreatment with quercetin reduced $\mathrm{H}_{2} \mathrm{O}_{2}$-induced $\alpha$-SNAP expression. Quercetin inhibits ROS-induced $\alpha$-SNAP overexpression in cardiomyocytes, which could be effectively applied for protecting cardiomyocytes from oxidative stress (Figure 10).

The major functions of the Ena/VASP-like (Evl) protein include the regulation of cytoskeletal dynamics and organization axon guidance, platelet aggregation, cell motility, and cell adhesion [34, 35]. However, several studies have shown that the Evl protein has another function in homologous pairing and strand exchange through interaction with RAD51 and RAD51B [36]. Because $\mathrm{H}_{2} \mathrm{O}_{2}$ targets DNA, oxidative stress causes base damage such as strand breaking in DNA. At this moment, the repaired mechanisms, including base excision repair (BER), transcription-coupled repair (TCR), mismatch repair (MMR), nonhomologous end-joining (NHEJ), translesion synthesis (TLS), global genome repair (GGR), and homologous recombination (HR), will been turned on [37]. ROS-treated cells exhibited DNA damage, stimulating homologous recombination. In this case, Evl expression increased in cardiomyocytes, but quercetin pretreatment reduced the expression of ROS-induced Evl (Figure 10). This suggests that quercetin may stabilize the DNA structure of ROS-damaged cardiomyocytes.

Isopentenyl-diphosphate delta-isomerase 1 , which is located in peroxisomes, catalyzes the isomerization of 1,3allylic rearrangement of the homoallylic substrate isopentenyl (IPP) to dimethylallyl diphosphate (DMAPP), which is a strong electrophile allylic isomer. DMAPP is also an important product in the synthesis of many lipophilic molecules such as sterols, ubiquinones, and terpenoids. Yochem et al. demonstrated that losing idi-1 gene is lethal in Caenorhabditis elegans, leading to accumulated and enlarged lysosomes and autophagosomes [38]. This study shows that ROS-treated block isopentenyl-diphosphate delta-isomerase 1 expression may induce cell death; however, quercetin pretreatment reversed isopentenyl-diphosphate delta-isomerase 1 expression in $\mathrm{H} 9 \mathrm{C} 2$ cell (Figure 10).

Elongation factor 1-alpha (EF-1 alpha) is a multifunctions protein that promotes peptide synthesis through GTPdependent binding of aminoacyl-tRNA to the A-site of 
ribosomes and binds to filamentous actin [39] and severs microtubules, leading to abnormal tetraploid cells and cell death [40]. In 1996, GaŁasiński demonstrated that quercetin prevents the peptide elongation by interacting with EF1 alpha in plant [41]. The present data show that $\mathrm{H}_{2} \mathrm{O}_{2}$ downregulates the expression of EF-1 alpha in H9C2 cells, whereas quercetin pretreatment reverses the expression of EF-1 alpha. Quercetin can prevent ROS-induced cytoskeleton damage and promote protein synthesis in cardiomyocytes (Figure 10).

Cellular antioxidant enzymes including superoxide dismutases (Mn-SOD and CuZn-SOD), catalase (CAT), peroxidases, and glutathione S-transferases regulate redox homeostasis in mammalian cells. Catalase and peroxidases scavenge $\mathrm{H}_{2} \mathrm{O}_{2}$ or convert it to hydroxyl radicals. Superoxide dismutases convert superoxide anions $\left(\mathrm{O}^{2-}\right)$ to $\mathrm{H}_{2} \mathrm{O}_{2}$. The observation of the oxidative state in this study demonstrates that ROS inhibits the MnSOD expression that leads to $\mathrm{O}^{2-}$ accumulation in cell. However, quercetin pretreatment not only reduces ROS production, but also prevents MnSOD expression in $\mathrm{H}_{2} \mathrm{O}_{2}$-treated $\mathrm{H} 9 \mathrm{C} 2$ cells (Figure 3).

Inflammation contributes to the pathophysiology of cardiac ischemia/reperfusion injury. Myocardial ischemia and reperfusion, sepsis, viral myocarditis, and immune rejection induce the inflammatory response [11]. Cardiac ischemia/reperfusion is an acute inflammatory response that may activate phospholipase A2, metabolizing arachidonic acid into inflammatory factors by cyclooxygenases (COX1 and COX-2), cytochrome P450, and lipoxygenase. These enzymes increase ROS production in the mitochondria. Xanthine oxidase and NADPH oxidase, which produce ROS in cells, result in inflammatory gene expression. These results suggest that quercetin blocks ROS-induced inflammatory responses such as COX-2, which converts arachidonic acid to prostaglandin (Figure 10).

STAT3, which belongs to the STAT protein family, is a protein transcription factor regulating many downstream signals for cell survival, apoptosis, proliferation, angiogenesis, and metabolic and anti-oxidative pathways [42]. Previous reports mentioned that oxidative stress activates the JAK2/STAT3/IL6 signal pathway in obese Zucker rats' fatty livers [15]. Furthermore, ROS production in hepatoma cells infected with Hepatitis C virus (HCV) activated STAT3 through JAK, Src kinase, and p38 MAP kinase pathways [43], and the decreased phosphorylation of p38 MAPK blocks the oxidative stress-induced senescence of myeloid leukemic cells [44]. PI-3K/AKT pathways, playing an important role in cell survival, proliferation, and growth, were activated by IL-1, leading to the proinflammatory gene activation of NF- $\kappa \mathrm{B}$ regulation. This study shows that $\mathrm{H}_{2} \mathrm{O}_{2}$ induced the phosphorylation of Src kinase, AKT, p38, and STAT3 (pY-705 and pS-727) in cardiomyocytes inhibited by pretreatment with quercetin. Quercetin protects H9C2 cells from ROS-induced hyperinflammatory responses that inhibit the activation of Src, p38, and STAT3 (Figure 10).

In summary, this study shows that quercetin inhibits Src kinase, a potential therapeutic target in vitro, and kinases such as FAK, p38, and STAT3. Thus, quercetin has

comprehensive effects on cardiomyocyte. The inhibition of an inflammatory response through STAT3 inactivation in cardiomyocyte may be beneficial for an ischemia/reperfusion injury model. Hence, quercetin should be tested in an animal model to verify its therapeutic role.

\section{Abbreviations}

2D-DIGE:

FBS:

$\mathrm{H}_{2} \mathrm{O}_{2}$ :

MS:

MALDI-TOF MS: Matrix-assisted laser desorption ionization-time-of-flight mass spectrometry

ROS:

STAT3:

DCFH-DA:

FACS:

FAK:

\section{Conflict of Interests}

The authors confirm that there is no conflict of interests.

\section{Acknowledgments}

This work was supported by NSC Grants (99-2311-B007-002, 100-2311-B-007-005, and 101-2311-B-007-011) from National Science Council, Taiwan, NTHU and CGH Grant (100N2723E1) from National Tsing Hua University, NTHU Booster Grant (99N2908E1) from National Tsing Hua University, Toward Word-Class University project from National Tsing Hua University (100N2051E1), and VGHUST Grant (99-P5-22) from Veteran General Hospitals University System of Taiwan.

\section{References}

[1] H. Takano, Y. Zou, H. Hasegawa, H. Akazawa, T. Nagai, and I. Komuro, "Oxidative stress-induced signal transduction pathways in cardiac myocytes: involvement of ROS in heart diseases," Antioxidants and Redox Signaling, vol. 5, no. 6, pp. 789-794, 2003.

[2] H. C. Chou, Y. W. Chen, T. R. Lee et al., "Proteomics study of oxidative stress and Src kinase inhibition in H9C2 cardiomyocytes: a cell model of heart ischemia-reperfusion injury and treatment," Free Radical Biology and Medicine, vol. 49, no. 1, pp. 96-108, 2010.

[3] M. J. Morgan and Z. G. Liu, "Reactive oxygen species in TNF $\alpha$ induced signaling and cell death," Molecules and Cells, vol. 30, no. 1, pp. 1-12, 2010.

[4] F. Rusnak and T. Reiter, "Sensing electrons: protein phosphatase redox regulation," Trends in Biochemical Sciences, vol. 25, no. 11, pp. 527-529, 2000.

[5] A. W. Boots, G. R. M. M. Haenen, and A. Bast, "Health effects of quercetin: from antioxidant to nutraceutical," European Journal of Pharmacology, vol. 585, no. 2-3, pp. 325-337, 2008. 
[6] J. Sanhueza, J. Valdes, R. Campos, A. Garrido, and A. Valenzuela, "Changes in the xanthine dehydrogenase/xanthine oxidase ratio in the rat kidney subjected to ischemia-reperfusion stress: preventive effect of some flavonoids," Research Communications in Chemical Pathology and Pharmacology, vol. 78, no. 2, pp. 211-218, 1992.

[7] B. Sun, G. B. Sun, J. Xiao et al., "Isorhamnetin inhibits $\mathrm{H}_{2} \mathrm{O}_{2}$ induced activation of the intrinsic apoptotic pathway in $\mathrm{H} 9 \mathrm{c} 2$ cardiomyocytes through scavenging reactive oxygen species and ERK inactivation," Journal of Cellular Biochemistry, vol. 113, pp. 473-485, 2012.

[8] M. Kyaw, M. Yoshizumi, K. Tsuchiya, K. Kirima, and T. Tamaki, "Antioxidants inhibit JNK and p38 MAPK activation but not ERK $1 / 2$ activation by angiotensin II in rat aortic smooth muscle cells," Hypertension Research, vol. 24, no. 3, pp. 251-261, 2001.

[9] D. Staedler, E. Idrizi, B. H. Kenzaoui, and L. Juillerat-Jeanneret, "Drug combinations with quercetin: doxorubicin plus quercetin in human breast cancer cells," Cancer Chemother Pharmacol, vol. 68, pp. 1161-1172, 2011.

[10] H. Kaiserová, T. Šimůnek, W. J. F. van der Vijgh, A. Bast, and E. Kvasničková, "Flavonoids as protectors against doxorubicin cardiotoxicity: role of iron chelation, antioxidant activity and inhibition of carbonyl reductase," Biochimica et Biophysica Acta, vol. 1772, no. 9, pp. 1065-1074, 2007.

[11] D. J. Marchant, J. H. Boyd, D. C. Lin, D. J. Granville, F. S. Garmaroudi, and B. M. McManus, "Inflammation in myocardial diseases," Circulation Research, vol. 110, pp. 126-144, 2012.

[12] G. Muthian and J. J. Bright, "Quercetin, a flavonoid phytoestrogen, ameliorates experimental allergic encephalomyelitis by blocking IL-12 signaling through JAK-STAT pathway in T lymphocyte," Journal of Clinical Immunology, vol. 24, no. 5, pp. 542-552, 2004.

[13] A. Tyagi, C. Agarwal, L. D. Dwyer-Nield, R. P. Singh, A. M. Malkinson, and R. Agarwal, "Silibinin modulates TNF-alpha and IFN-gamma mediated signaling to regulate COX2 and iNOS expression in tumorigenic mouse lung epithelial LM2 cells," Molecular Carcinogenesis, vol. 51, no. 10, pp. 832-842, 2012.

[14] T. Yagi, H. Yoshioka, T. Wakai, T. Kato, T. Horikoshi, and H. Kinouchi, "Activation of signal transducers and activators of transcription 3 in the hippocampal CA1 region in a rat model of global cerebral ischemic preconditioning," Brain Research, vol. 1422, pp. 39-45, 2011.

[15] G. S. Dikdan, S. C. Saba, A. N. Dela Torre, J. Roth, S. Wang, and B. Koneru, "Role of oxidative stress in the increased activation of signal transducers and activators of transcription-3 in the fatty livers of obese Zucker rats," Surgery, vol. 136, no. 3, pp. 677-685, 2004.

[16] C. C. Chen, Y. C. Lu, Y. W. Chen et al., "Hemopexin is upregulated in plasma from type 1 diabetes mellitus patients: role of glucose-induced ROS," Journal of Proteomics, vol. 75, no. 12, pp. 3760-3777, 2012.

[17] C. L. Wu, H. C. Chou, C. S. Cheng et al., "Proteomic analysis of UVB-induced protein expression- and redox-dependent changes in skin fibroblasts using lysine- and cysteine-labeling two-dimensional difference gel electrophoresis," Journal of Proteomics, vol. 75, pp. 1991-2014, 2012.

[18] K. Raedschelders, D. M. Ansley, and D. D. Chen, “The cellular and molecular origin of reactive oxygen species generation during myocardial ischemia and reperfusion," Pharmacology \& Therapeutics, vol. 133, pp. 230-255, 2012.
[19] J. T. Hwang, D. Y. Kwon, O. J. Park, and M. S. Kim, "Resveratrol protects ROS-induced cell death by activating AMPK in H9c2 cardiac muscle cells," Genes and Nutrition, vol. 2, no. 4, pp. 323$326,2008$.

[20] Z. Liao, D. Yin, W. Wang et al., "Cardioprotective effect of sasanquasaponin preconditioning via bradykinin-NO pathway in isolated rat heart," Phytotherapy Research, vol. 23, no. 8, pp. 1146-1153, 2009.

[21] Z. H. Shao, K. R. Wojcik, A. Dossumbekova et al., "Grape seed proanthocyanidins protect cardiomyocytes from ischemia and reperfusion injury via Akt-NOS signaling," Journal of Cellular Biochemistry, vol. 107, no. 4, pp. 697-705, 2009.

[22] S. Y. Han, H. X. Li, X. Ma, K. Zhang, Z. Z. Ma, and P. F. Tu, "Protective effects of purified safflower extract on myocardial ischemia in vivo and in vitro," Phytomedicine, vol. 16, no. 8, pp. 694-702, 2009.

[23] N. Lu, Y. Sun, and X. Zheng, "Orientin-induced cardioprotection against reperfusion is associated with attenuation of mitochondrial permeability transition," Planta Medica, vol. 77, no. 10, pp. 984-991, 2011.

[24] S. Huveneers and E. H. J. Danen, "Adhesion signalingcrosstalk between integrins, Src and Rho," Journal of Cell Science, vol. 122, no. 8, pp. 1059-1069, 2009.

[25] A. B. Stein, X. L. Tang, Y. Guo, Y. T. Xuan, B. Dawn, and R. Bolli, "Delayed adaptation of the heart to stress: late preconditioning," Stroke, vol. 35, no. 11, pp. 2676-2679, 2004.

[26] M. A. Krasilnikov, "Phosphatidylinositol-3 kinase sependent pathways: the role in control of cell growth, survival, and malignant transformation," Biochemistry, vol. 65, no. 1, pp. 5967, 2000.

[27] S. Miravet, J. Piedra, J. Castaño et al., "Tyrosine phosphorylation of plakoglobin causes contrary effects on its association with desmosomes and adherens junction components and modulates $\beta$-catenin-mediated transcription," Molecular and Cellular Biology, vol. 23, no. 20, pp. 7391-7402, 2003.

[28] M. Aldemir, G. Ozgun, E. Onen, E. Okulu, and O. Kayigil, "Quercetin has a protective role on histopathological findings on testicular ischaemia-reperfusion injury in rats," Andrologia, vol. 44, supplement 1, pp. 479-483, 2012.

[29] D. Dekanski, V. Selakovic, V. Piperski, Z. Radulovic, A. Korenic, and L. Radenovic, "Protective effect of olive leaf extract on hippocampal injury induced by transient global cerebral ischemia and reperfusion in Mongolian gerbils," Phytomedicine, vol. 18, pp. 1137-1143, 2011.

[30] A. K. Pandey, P. P. Hazari, R. Patnaik, and A. K. Mishra, "The role of ASICla in neuroprotection elicited by quercetin in focal cerebral ischemia," Brain Research, vol. 1383, pp. 289-299, 2011.

[31] X. Cao, M. Liu, J. Tuo, D. Shen, and C. C. Chan, "The effects of quercetin in cultured human RPE cells under oxidative stress and in $\mathrm{Ccl} 2 / \mathrm{Cx} 3 \mathrm{crl}$ double deficient mice," Experimental Eye Research, vol. 91, no. 1, pp. 15-25, 2010.

[32] M. Skalski, N. Sharma, K. Williams, A. Kruspe, and M. G. Coppolino, "SNARE-mediated membrane traffic is required for focal adhesion kinase signaling and Src-regulated focal adhesion turnover," Biochimica et Biophysica Acta, vol. 1813, no. 1, pp. 148-158, 2011.

[33] J. W. Calvert, S. Gundewar, M. Yamakuchi et al., "Inhibition of N-ethylmaleimide-sensitive factor protects against myocardial ischemia/reperfusion injury," Circulation Research, vol. 101, no. 12, pp. 1247-1254, 2007.

[34] L. D. Hu, H. F. Zou, S. X. Zhan, and K. M. Cao, "EVL (Ena/VASP-like) expression is up-regulated in human breast 
cancer and its relative expression level is correlated with clinical stages," Oncology Reports, vol. 19, no. 4, pp. 1015-1020, 2008.

[35] S. J. Wanner, M. C. Danos, J. L. Lohr, and J. R. Miller, "Molecular cloning and expression of Ena/Vasp-like (Evl) during Xenopus development," Gene Expression Patterns, vol. 5, no. 3, pp. 423428, 2005.

[36] M. Takaku, S. Machida, N. Hosoya et al., "Recombination activator function of the novel RAD51- and RAD51B-binding protein, human EVL," Journal of Biological Chemistry, vol. 284, no. 21, pp. 14326-14336, 2009.

[37] G. Slupphaug, B. Kavli, and H. E. Krokan, "The interacting pathways for prevention and repair of oxidative DNA damage," Mutation Research, vol. 531, no. 1-2, pp. 231-251, 2003.

[38] J. Yochem, D. H. Hall, L. R. Bell, E. M. Hedgecock, and R. K. Herman, "Isopentenyl-diphosphate isomerase is essential for viability of Caenorhabditis elegans," Molecular Genetics and Genomics, vol. 273, no. 2, pp. 158-166, 2005.

[39] T. Izawa, Y. Fukata, T. Kimura, A. Iwamatsu, K. Dohi, and K. Kaibuchi, "Elongation factor- $1 \alpha$ is a novel substrate of Rho-associated kinase," Biochemical and Biophysical Research Communications, vol. 278, no. 1, pp. 72-78, 2000.

[40] Y. Kobayashi and S. Yonehara, "Novel cell death by downregulation of eEF1A1 expression in tetraploids," Cell Death and Differentiation, vol. 16, no. 1, pp. 139-150, 2009.

[41] W. Gałasiński, "Eukaryotic polypeptide elongation system and its sensitivity to the inhibitory substances of plant origin," Proceedings of the Society for Experimental Biology and Medicine, vol. 212, no. 1, pp. 24-37, 1996.

[42] H. Wang, F. Lafdil, X. Kong, and B. Gao, "Signal transducer and activator of transcription 3 in liver diseases: a novel therapeutic target," International Journal of Biological Sciences, vol. 7, no. 5, pp. 536-550, 2011.

[43] G. Waris, J. Turkson, T. Hassanein, and A. Siddiqui, "Hepatitis C virus (HCV) constitutively activates STAT-3 via oxidative stress: role of STAT-3 in HCV replication," Journal of Virology, vol. 79, no. 3, pp. 1569-1580, 2005.

[44] Y. Xiao, P. Zou, J. Wang, H. Song, J. Zou, and L. Liu, "Lower phosphorylation of p38 MAPK blocks the oxidative stressinduced senescence in myeloid leukemic CD $34^{+} \mathrm{CD} 38^{-}$cells," Journal of Huazhong University of Science and Technology, vol. 32, no. 3, pp. 328-333, 2012. 


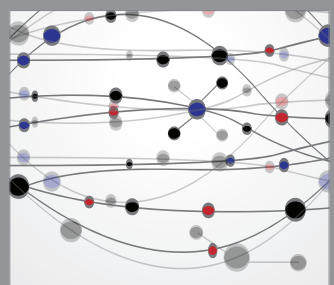

The Scientific World Journal
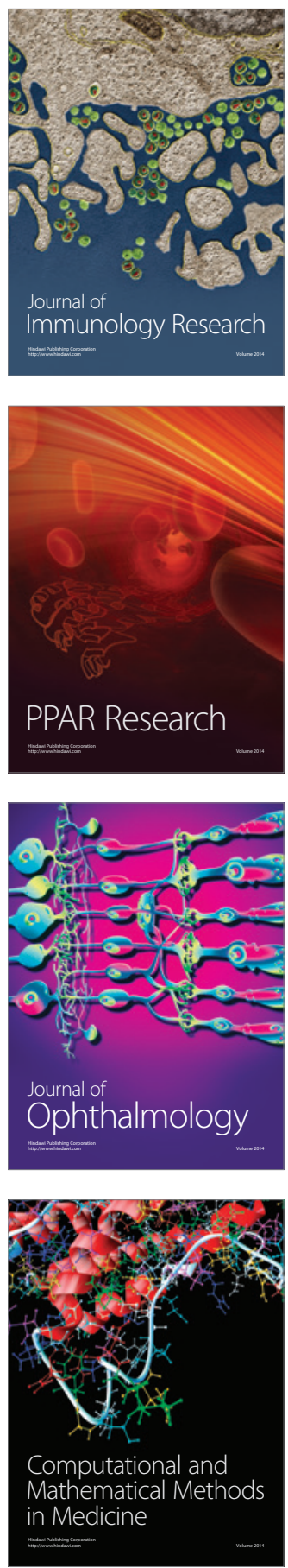

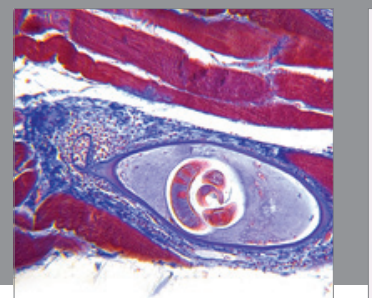

Gastroenterology

Research and Practice
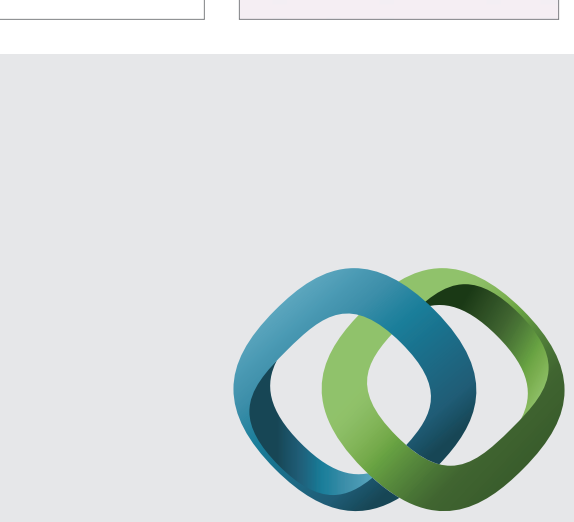

\section{Hindawi}

Submit your manuscripts at

http://www.hindawi.com
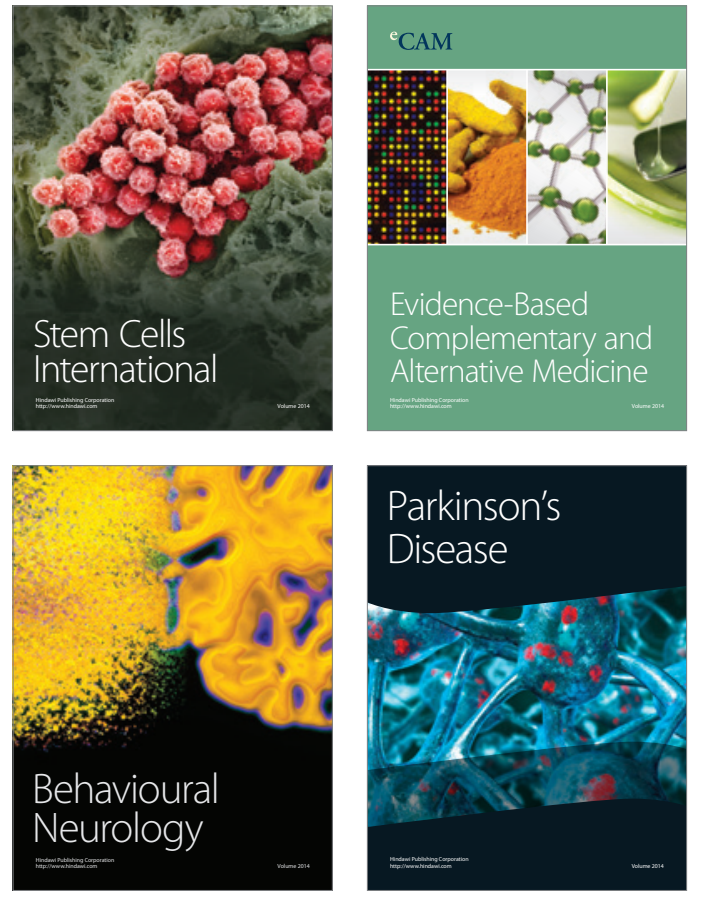
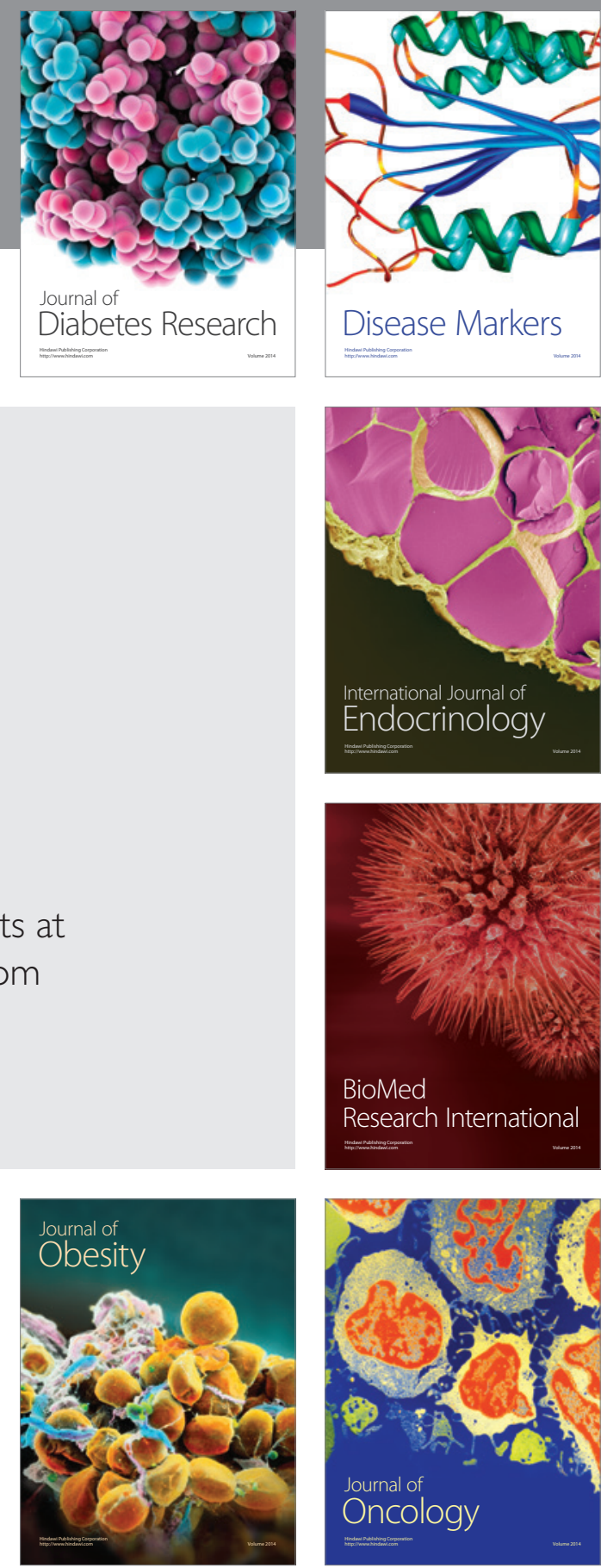

Disease Markers
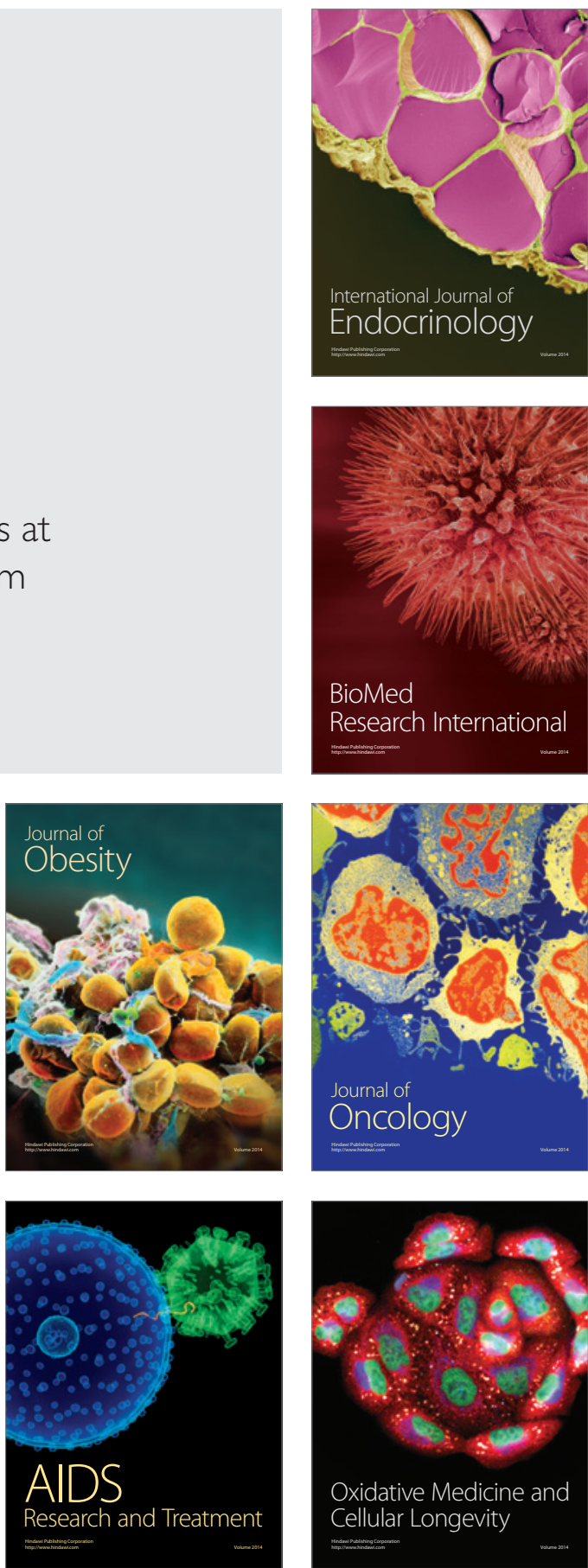